ВІСНИК

ОДЕСЬКОГО НАЦІОНАЛЬНОГО

МОРСЬКОГО УНІВЕРСИТЕТУ

№ 2 (65), 2021
HERALD

OF THE ODESSA NATIONAL

MARITIME UNIVERSITY № 2 (65), 2021

УДК 629.5.01

DOI 10.47049/2226-1893-2021-2-47-83

\title{
АНАЛІЗ ФЛОТУ РІЧКОВИХ \\ КРУЇЗНИХ ПАСАЖИРСЬКИХ СУДЕН КИТАЮ
}

\section{О.Г. Сгоров}

к.т.н., генеральний директор

Морське інженерне бюро, Украӥна, Одеса

Анотація. Виконано дослідження флоту китайських річкових круїзних пасажирських суден (РКПС), визначені основні круїзні компанії: "Century Cruises», "Changjiang Cruises», "China Goddess Cruises», "President Cruises», «Victoria Cruises», «Yangtze Gold Cruises», «Sanctuary Yangzi Explorer».

На січень 2021 року в експлуатаиії на річиі Янизи знаходяться 29 РКПС міжнародного рівня. Ще 6 РКПС добудовуються $і$ будуть здані в 2021-2023 роках. Середній вік праџюючих РКПС 12,1 рік. Сумарна пасажиромісткість 10889 чоловік, з урахуванням суден, які будуть здані в експлуатацію найближчим часом, 14739 чоловік. Середня завантаженість РКПС в 2017 ройі склала 75-82\%.

Нові судна для «в '̈зних» туристів проектуються і будуються $з$ зірковістю 5+*. Враховуються особливості китайського регіону: східні майстер-класи, курси каліграфії, тайизи і традииійної китайської медииини, окремі віп ресторани і лаунж-зони, кімнати для гри в маджонг, китайське караоке KTV, лекиії про історію та культуру КНР, китайські елементи в інтер'єрах. Площза стандартних кают варіюється від 15 до $31 м^{2}$ (на єдиному ультра-люксовому китайському РКПС «Yangtze Explorег»), кают класу «Люкс» - від 22 до $176 \mathrm{M}^{2}$. Всі каюти, за винятком внутрішніх, з балконами.

Приділясться особлива увага комфортабельності на борту і екологічності суден: з метою зменшення шуму $і$ вібраиії нові РКПС будуються з гвинто-рульовими колонками на електрорусі, встановлюються системи очищення стічних вод, відходи перероблюються прямо на борту.

Ключові слова: Китай, річкове судно, круїз, дослідження основних характеристик, аналіз.

УДК 629.5.01

DOI 10.47049/2226-1893-2021-2-47-83

\section{АНАЛИЗ ФЛОТА РЕЧНЫХ \\ КРУИЗНЫХ ПАССАЖИРСКИХ СУДОВ КИТАЯ}

\author{
А.Г. Егоров \\ к.т.н., генеральный директор
}

Морское инженерное бюро, Украина, Одесса

(C) Сгоров О.Г., 2021 
ВІСНИК

ОДЕСЬКОГО НАЦІОНАЛЬНОГО

МОРСЬКОГО УНІВЕРСИТЕТУ № 2 (65), 2021
HERALD

OF THE ODESSA NATIONAL

MARITIME UNIVERSITY № 2 (65), 2021

Аннотация. Выполнено исследование флота китайских речных круизных пассажирских судов (РКПС), определены основные круизные компании: "Century Cruises», "Changjiang Cruises», "China Goddess Cruises», «President Cruises», «Victoria Cruises», «Yangtze Gold Cruises», «Sanctuary Yangzi Explorer».

На январь 2021 года в эксплуатачии на реке Янизы находятся 29 РКПС международного уровня. Еще 6 РКПС достраиваются и будут сданы в 2021-2023 годах. Средний возраст работающии РКПС 12,1 год. Суммарная пассажировместимость 10889 человек, с учетом судов, которые будут сданы в эксплуатацию в ближайшее время, 14739 человек. Средняя загруженность РКПС в 2017 году составила 75-82 \%.

Новые суда для «въездныхх туристов проектируются и строятся со звездностью 5+*. Учитываются особенности китайского региона: восточные мастер-классы, курсы каллиграфии, тайизи и традиционной китайской медицины, отдельные вип рестораны и лаунж-зоны, комнаты для игры в маджонг, китайское караоке KTV, лекиии об истории и культуре КНР, китайские элементы в интерьерах. Площадь стандартных кают варьируется от 15 до $31 \mathrm{M}^{2}$ (на единственном ультра-люксовом китайском РКПС «Yangtze Explorer»), кают класса «Люкс» - от 22 до $176 \mathrm{~m}^{2}$. Все каюты, за исключением внутренних, с балконами.

Уделяется особое внимание комфортабельности на борту и экологичности судов: с целью уменьшения шума и вибрации новые РКПС строятся с винто-рулевыми колонками на электродвижении, устанавливаются системы очистки сточных вод, отходы перерабатываются прямо на борту.

Ключевые слова: Китай, речное судно, круиз, исследование основных характеристик, инновации.

UDC 629.5.01629.5.01

DOI 10.47049/2226-1893-2021-2-47-83

\title{
ANALYSIS OF CHINESE RIVER CRUISE PASSENGER SHIPS
}

\author{
A. Egorov \\ Candidate of Technical Sciences, General Director \\ Marime Engineering Bureau, Ukraine, Odessa
}

Abstract. Study of the fleet of Chinese river cruise passenger ships (RCPS) was carried out, main cruise companies were identified: "Century Cruises», "Changjiang Cruises», "China Goddess Cruises», "President Cruises», «Victoria Cruises», «Yangtze Gold Cruises», «Sanctuary Yangzi Explorer». 
As of January 2021, there were 29 international RCPS in operation on the Yangtze River. Another 6 RCPS are being completed and will be commissioned in 2021-2023. The mean age of working RCPS is 12,1 years. Total passenger capacity is 10889 passengers, including ships that will be built in the near future 14739 passengers. The average workload of RCPS in 2017 was $75-82 \%$.

New ships for international tourists are designed and built with $5+*$ star rating. Features of Chinese region are taken into account: eastern master classes, courses of calligraphy, tai chi and traditional Chinese medicine, individual VIP restaurants and lounge zones, rooms for playing mahjong, Chinese karaoke KTV, lectures about history and culture of the PRC, Chinese elements in interiors. The area of standard cabins varies from 15 to $31 \mathrm{~m}^{2}$ (on the only ultra-luxury Chinese RCPS «Yangtze Explorer»), luxury cabins - from 22 to $176 \mathrm{~m}^{2}$. All cabins, except internal ones, have balconies.

Special attention is paid to the comfort onboard and the environmental friendliness of ships: in order to reduce noise and vibration new RCPS are built with fixed pitch rudder-propellers on electric propulsion, sewage treatment systems are installed, waste is processed directly onboard. analysis.

Keywords: China, river ship, cruise, research of main characteristics,

Постановка проблеми. Круїзи на річкових суднах у всіх країнах світу стають популярнішими 3 кожним роком. Розширюється географія круїзів, змінюються підходи до надання послуг на борту, модернізуються і будуються нові річкові круїзні пасажирські судна (РКПС) $[1,2]$. Круїзи по внутрішніх водних шляхах (ВВШ) КНР, поряд 3 європейськими, російськими, нільськими, американськими і азіатськими (річка Меконг) круїзами, привертають велику кількість як «в'їзних», так і місцевих туристів. У XXI столітті, особливо в другому десятилітті, відбулася зміна підходів до проектування таких суден - від копіювання європейських до створення власних оригінальних рішень.

Метою статті $\epsilon$ вивчення флоту китайських РКПС і його характеристик, з метою використання при проектуванні нових РКПС для ВВШ в європейських країнах.

Виклад основного матеріалу. У першій частині роботи були виконані дослідження ринку річкових круїзів КНР, а також технічних рішень, що застосовуються при проектуванні і будівництві РКПС [3]. Ринок китайських річкових круїзів розвивається, будуються нові судна.

Основними круїзними компаніями, які обслуговують, в тому числі, «в 'їзиих туристів на річці Янцзи і оперують РКПС міжнародного рівня, є: «Century Cruises», «Changjiang Cruises», «China Goddess Cruises», «President Cruises», «Victoria Cruises», «Yangtze Gold Cruises», «Sanctuary Yangzi Explorer» [4]. Розподіл китайського флоту РКПС міжнародного 
ВІСНИК

ОДЕСЬКОГО НАЦІОНАЛЬНОГО

МОРСЬКОГО УНІВЕРСИТЕТУ

№ 2 (65), 2021
HERALD

OF THE ODESSA NATIONAL

MARITIME UNIVERSITY № 2 (65), 2021

рівня та основні характеристики наведені в таблиці 1, зведені дані по флоту РКПС міжнародного рівня - в таблиці 2.

На січень 2021 року в експлуатації на річці Янцзи знаходяться 29 РКПС міжнародного рівня. Ще 6 РКПС добудовуються і будуть здані в 2021-2023 роках. Середній вік працюючих РКПС 12,1 рік. Сумарна пасажиромісткість 10889 чоловік, з урахуванням суден, які будуть здані в експлуатацію найближчим часом, 14739 чоловік. Середня завантаженість РКПС у 2017 році склала 75-82 \% [14].

Круїзна компанія «Century Cruises». Компанія на річці Янцзи, яка найбільш динамічно розвивається. Флот компанії складається 3 6 РКПС міжнародного рівня. Останнє РКПС компанії «Century Glory» було здано в експлуатацію в 2019 році (загальний вигляд див. рисунок 1 , план палуб - рисунок 2). Вартість будівництва головного судна склала 300 млн. юанів (46 млн. доларів США) [4]. Ще 4 однотипних 3 «Century Glory» РКПС будуються і будуть здані в 2021-2023 роках.
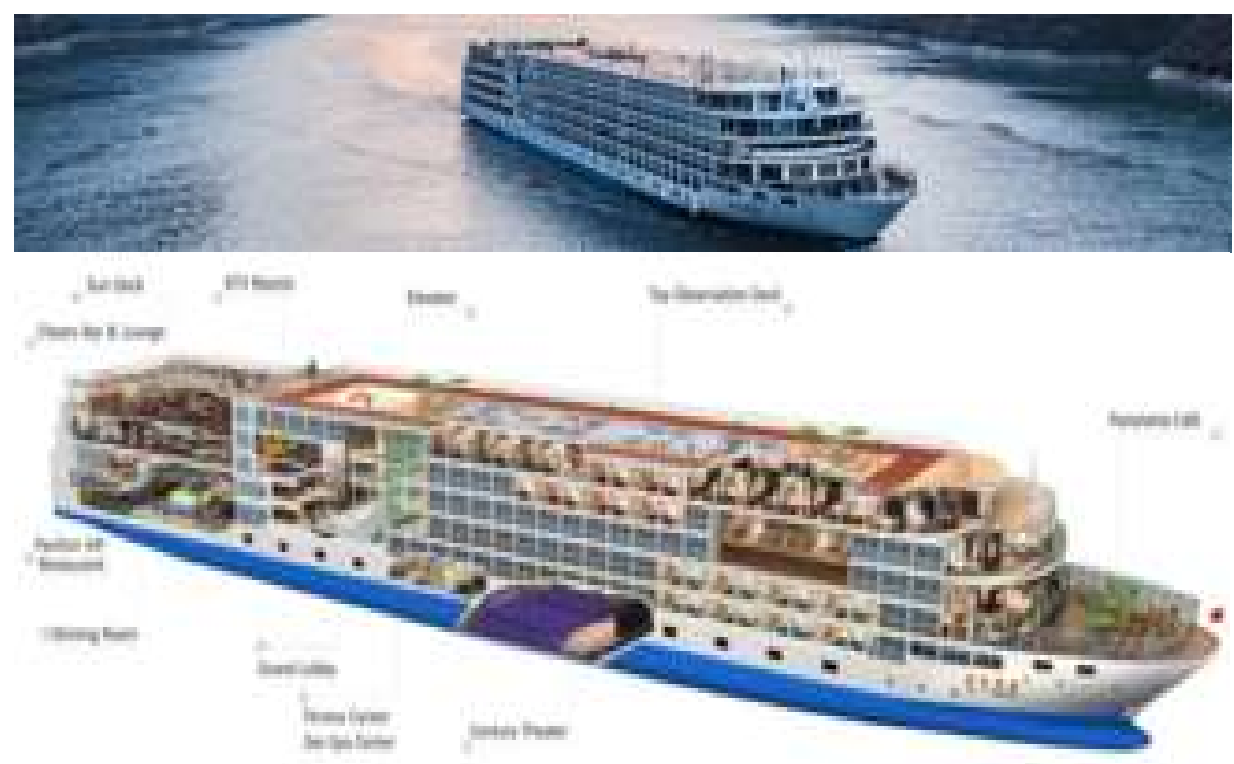

Рис. 1. Загальний вигляд РКПС «Century Glory» 2019 року будівниитва

Джерело: [5]

Одна 3 перших круїзних компаній, яка почала будувати РКПС зі збільшеними габаритними розміреннями в результаті запуску в роботу гідровузла «Три ущелини». Загальне розташування такого РКПС «Century Legend» представлено на рисунку 3. 
ВІСНИК

ОДЕСЬКОГО НАЦІОНАЛЬНОГО МОРСЬКОГО УНІВЕРСИТЕТУ

№ 2 (65), 2021
HERALD

OF THE ODESSA NATIONAL

MARITIME UNIVERSITY

№ 2 (65), 2021 
ВІСНИК

ОДЕСЬКОГО НАЦІОНАЛЬНОГО МОРСЬКОГО УНІВЕРСИТЕТУ

№ 2 (65), 2021
HERALD

OF THE ODESSA NATIONAL

MARITIME UNIVERSITY

№ 2 (65), 2021 
ВІСНИК

ОДЕСЬКОГО НАЦІОНАЛЬНОГО МОРСЬКОГО УНІВЕРСИТЕТУ

№ 2 (65), 2021
HERALD

OF THE ODESSA NATIONAL

MARITIME UNIVERSITY

№ 2 (65), 2021 
ВІСНИК

ОДЕСЬКОГО НАЦІОНАЛЬНОГО

МОРСЬКОГО УНІВЕРСИТЕТУ № 2 (65), 2021
HERALD

OF THE ODESSA NATIONAL

MARITIME UNIVERSITY

№ 2 (65), 2021

Таблиия 2

Зведені дані з урахуванням суден, що будуються для круїзних компаній

\begin{tabular}{|l|c|c|c|}
\hline \multicolumn{1}{|c|}{ Назва компанії } & $\begin{array}{c}\text { Кількість РКПС } \\
\text { міжнародного } \\
\text { рівня, од. }\end{array}$ & $\begin{array}{c}\text { Середній вік } \\
\text { (тільки в експлуа- } \\
\text { тації), роки }\end{array}$ & $\begin{array}{c}\text { Сумарна } \\
\text { пасажиромісткість, } \\
\text { чол. }\end{array}$ \\
\hline Century Cruises & 10 & 10,0 & $4942(2342)$ \\
\hline Changjiang Cruises & 3 & 12,5 & $1270(670)$ \\
\hline China Goddess Cruises & 3 & 8,0 & $1284(634)$ \\
\hline President Cruises & 3 & 8,0 & 1294 \\
\hline Victoria Cruises & 8 & 18,8 & 2304 \\
\hline Yangtze Gold Cruises & 7 & 8,9 & 124 \\
\hline $\begin{array}{l}\text { Sanctuary Yangzi } \\
\text { Explorer }\end{array}$ & 1 & 13 & $\mathbf{1 4 7 3 9}$ \\
\hline Взагалi & $\begin{array}{c}\mathbf{3 5}(\mathbf{2 9} \text { в } \\
\text { експлуатації, } \\
\text { 6 будуються) }\end{array}$ & $\mathbf{1 2 , 1}$ & $\mathbf{( 1 0 8 8 9}$ фактична) \\
\hline
\end{tabular}

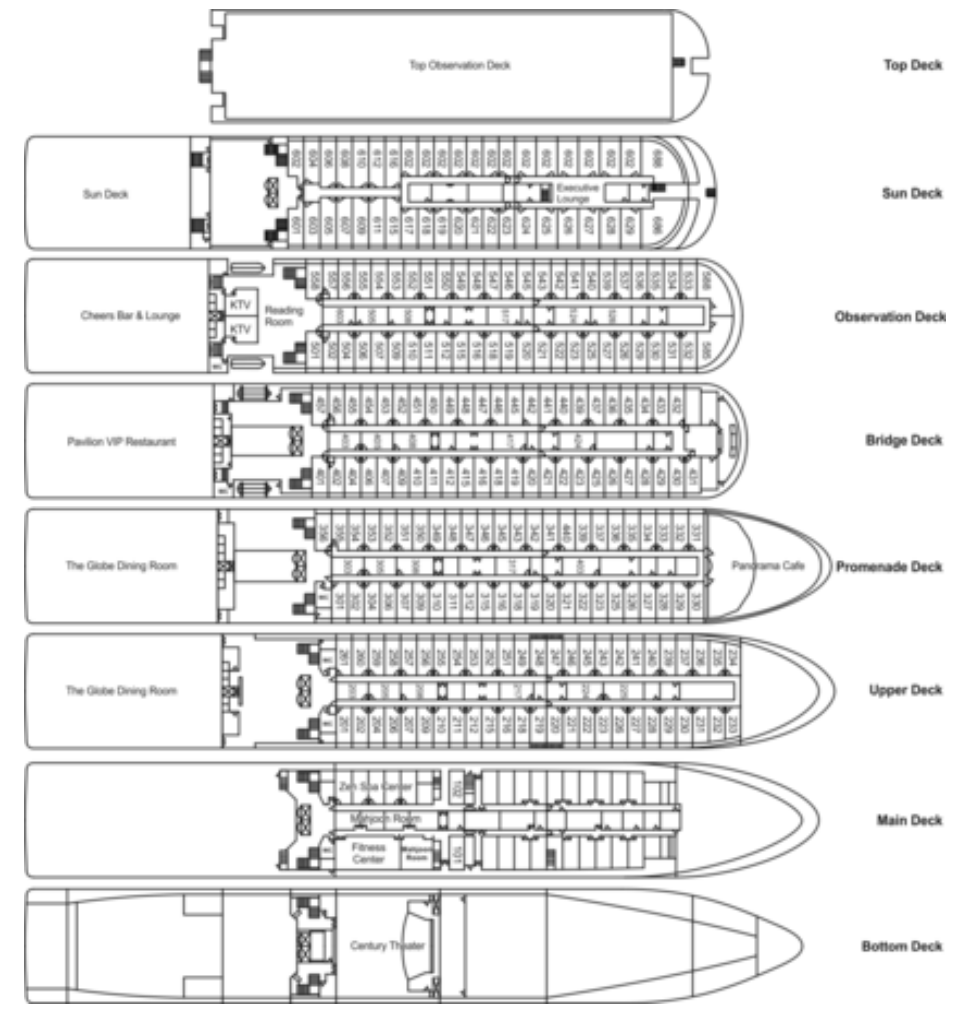

Рис. 2. План палуб РКПС «Century Glory» 2019 року будівництва

Дюерело: [5] 
ВІСНИК

ОДЕСЬКОГО НАЦІОНАЛЬНОГО МОРСЬКОГО УНІВЕРСИТЕТУ № 2 (65), 2021
HERALD

OF THE ODESSA NATIONAL MARITIME UNIVERSITY № 2 (65), 2021
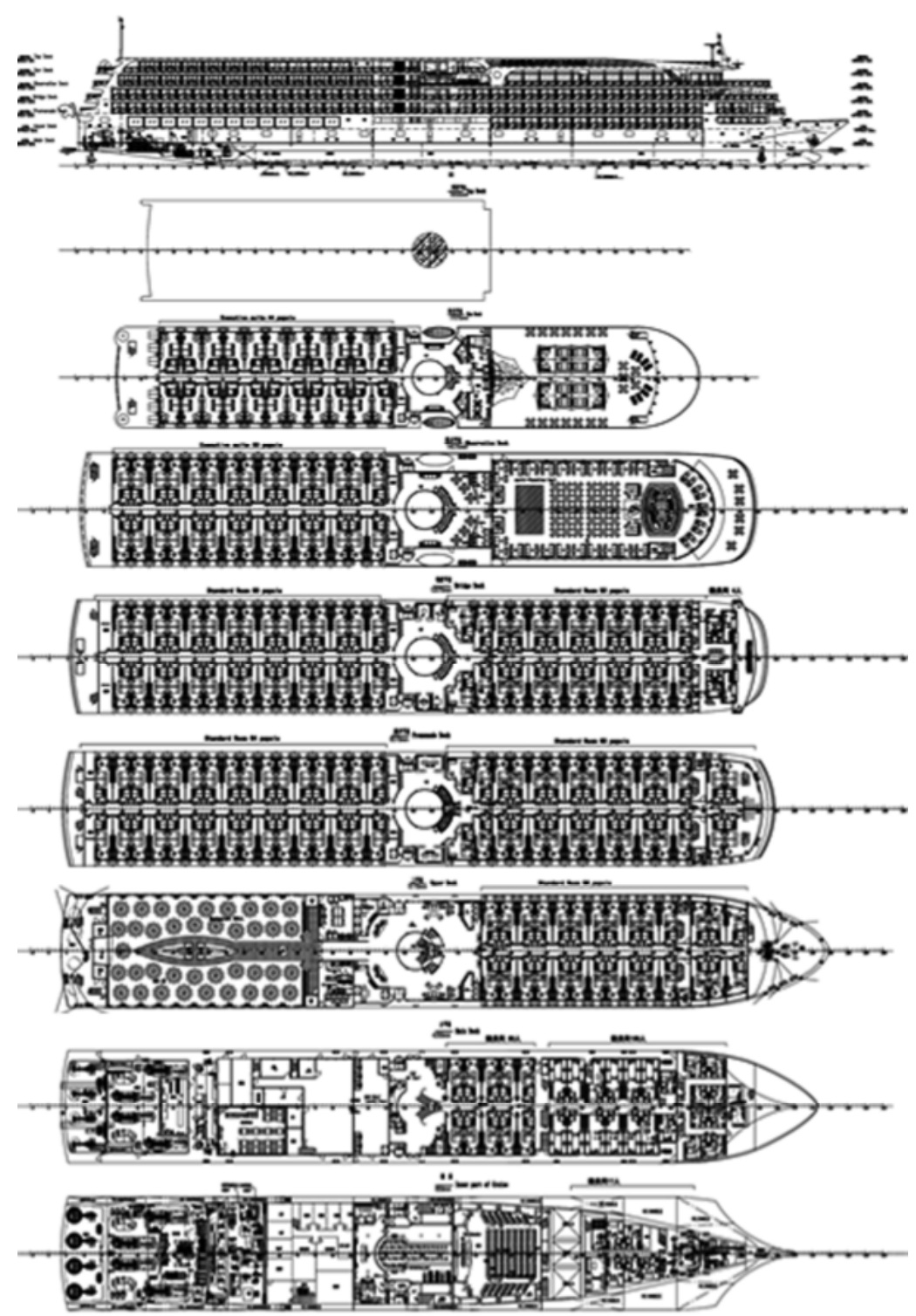

Рис. 3. Загальне розташування РКПС «Century Legend»

\section{Джерело: [5]}

Практично всі РКПС компанії працюють 3 «в 'їзними» туристами, рівень сервісу відповідає європейським $5^{*}$. балконами.

Площа кают на суднах компанії наведена в таблиці 3. Всі каюти 3 
ВІСНИК

ОДЕСЬКОГО НАЦІОНАЛЬНОГО

МОРСЬКОГО УНІВЕРСИТЕТУ

№ 2 (65), 2021
HERALD

OF THE ODESSA NATIONAL

MARITIME UNIVERSITY № 2 (65), 2021

Загальний вигляд стандартної каюти на суднах типу «Century Glory» наведено на рисунку 4, президентського люксу - на рисунку 5. Дизайн кают європейський.

Практично всі РКПС компанії працюють 3 «в'їзними» туристами, рівень сервісу відповідає європейським $5^{*}$. балконами.

Площа кают на суднах компанії наведена в таблиці 3. Всі каюти 3

Загальний вигляд стандартної каюти на суднах типу «Century Glory» наведено на рисунку 4, президентського люксу - на рисунку 5. Дизайн кают європейський.

Таблиия 3

Площуа кают на суднах компанії «Cеntury Cruises»

\begin{tabular}{|l|c|c|c|c|}
\hline \multicolumn{1}{|c|}{ Назва судна } & $\begin{array}{c}\text { Кількість } \\
\text { стандартних } \\
\text { кают, од. }\end{array}$ & $\begin{array}{c}\text { Площа } \\
\text { стандартних } \\
\text { кают, }{ }^{2}\end{array}$ & $\begin{array}{c}\text { Кількість } \\
\text { кают класу } \\
\text { «Люкс», од. }\end{array}$ & $\begin{array}{c}\text { Площа } \\
\text { кают класу } \\
\text { «Люкс», } \mathrm{m}^{2}\end{array}$ \\
\hline Century Glory & 232 & $20-26$ & 28 & $33-85$ \\
\hline Century Legend & 156 & 28 & 40 & $30-106$ \\
\hline Century Paragon & 156 & 28 & 40 & $30-106$ \\
\hline Century Emerald & 112 & 25 & 20 & $28-78$ \\
\hline Century Sun & 143 & 25,9 & 10 & $30-35,6$ \\
\hline Century Sky & 143 & 25,9 & 10 & $30-35,6$ \\
\hline
\end{tabular}

Джерело: [5]
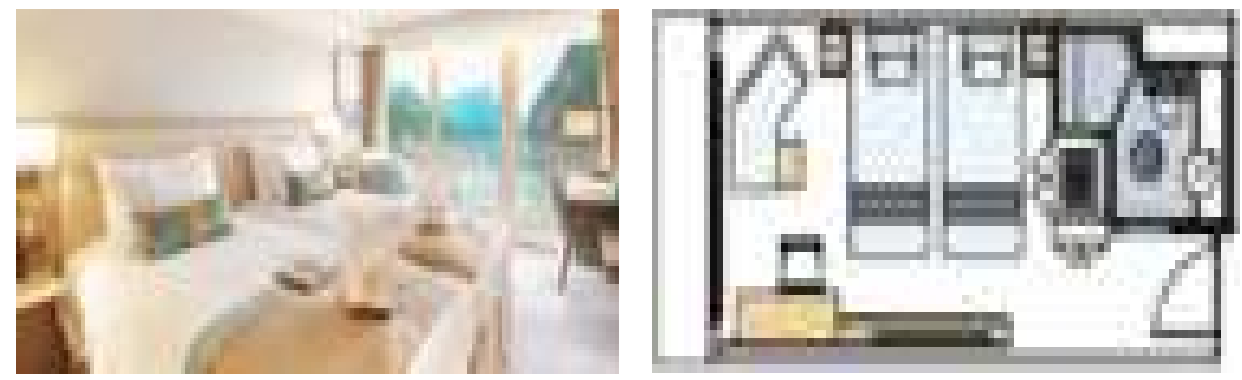

Рис. 4. Стандартна каюта на «Century Glory»

Джерело: [5]

Загальний вигляд стандартної каюти на суднах типу «Century Legend» наведено на рисунку 6 , люксу - на рисунку 7. Дизайн кают в східному стилі. 


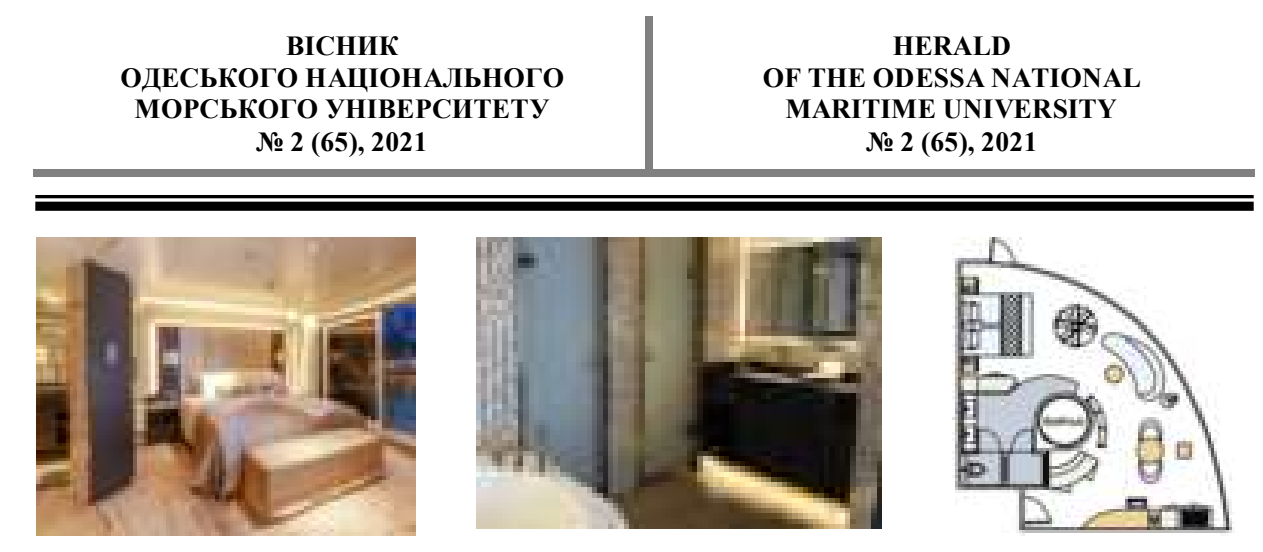

Рис. 5. Каюта класу «Президентський люкс» на «Century Glory»

Джерело: [5]
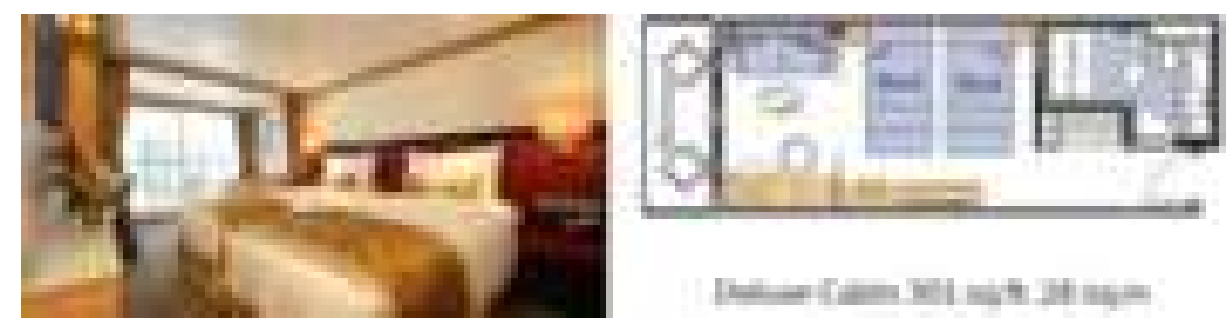

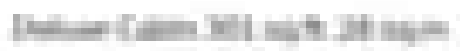

Pис. 6. Стандартна каюта на «Century Legend»

Джерело: [5]
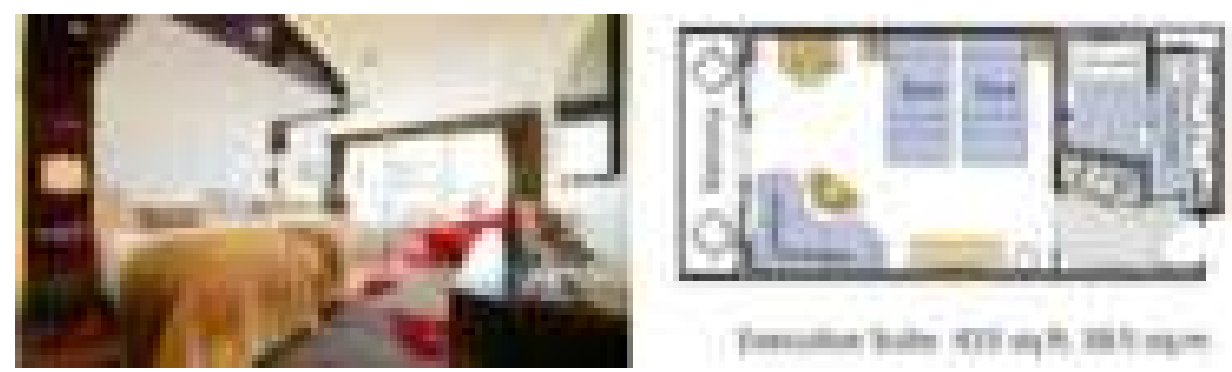

Fins

Pис. 7. Каюта класу «люкс» на «Century Legend»

Джерело: [5]

На РКПС «Century Glory» передбачений двох'ярусний ресторан 3 невеликими столами на 2-4 людини (див. рисунок 8). Всього на судні 2 ресторани, 1 лаунж-бар і 1 кафе.

Загальний вигляд лобі та рецепції РКПС «Century Glory» наведено на рисунку 9.

Загальні види приміщень і сонячної палуби РКПС «Century Glory» наведені на рисунках 10 та 11. 
ВІСНИК

ОДЕСЬКОГО НАЦІОНАЛЬНОГО

МОРСЬКОГО УНІВЕРСИТЕТУ

№ 2 (65), 2021
HERALD

OF THE ODESSA NATIONAL

MARITIME UNIVERSITY № 2 (65), 2021

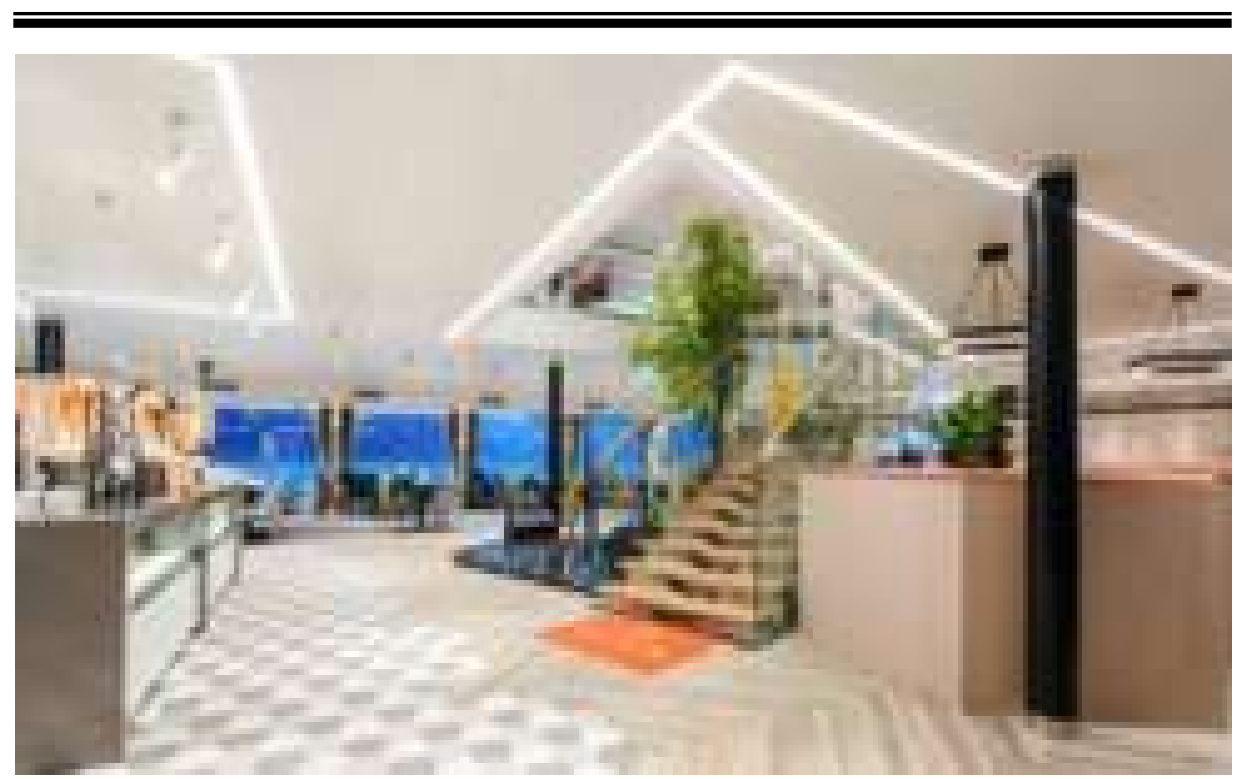

Pис. 8. Двох'ярусний ресторан нового типу на РКПС "Century Glory»

Джерело: [5]

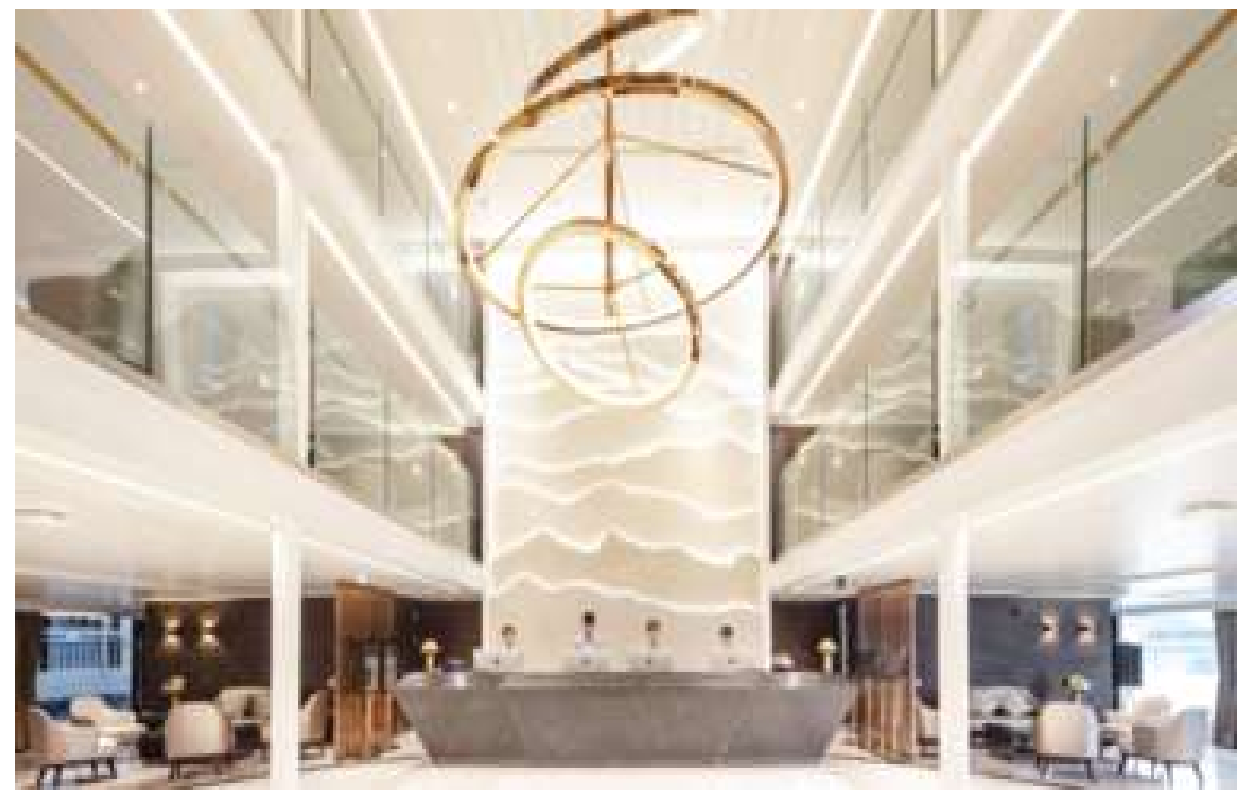

Рис. 9. Лобі та рецепиія на РКПС «Century Glory»

Джерело: [5] 


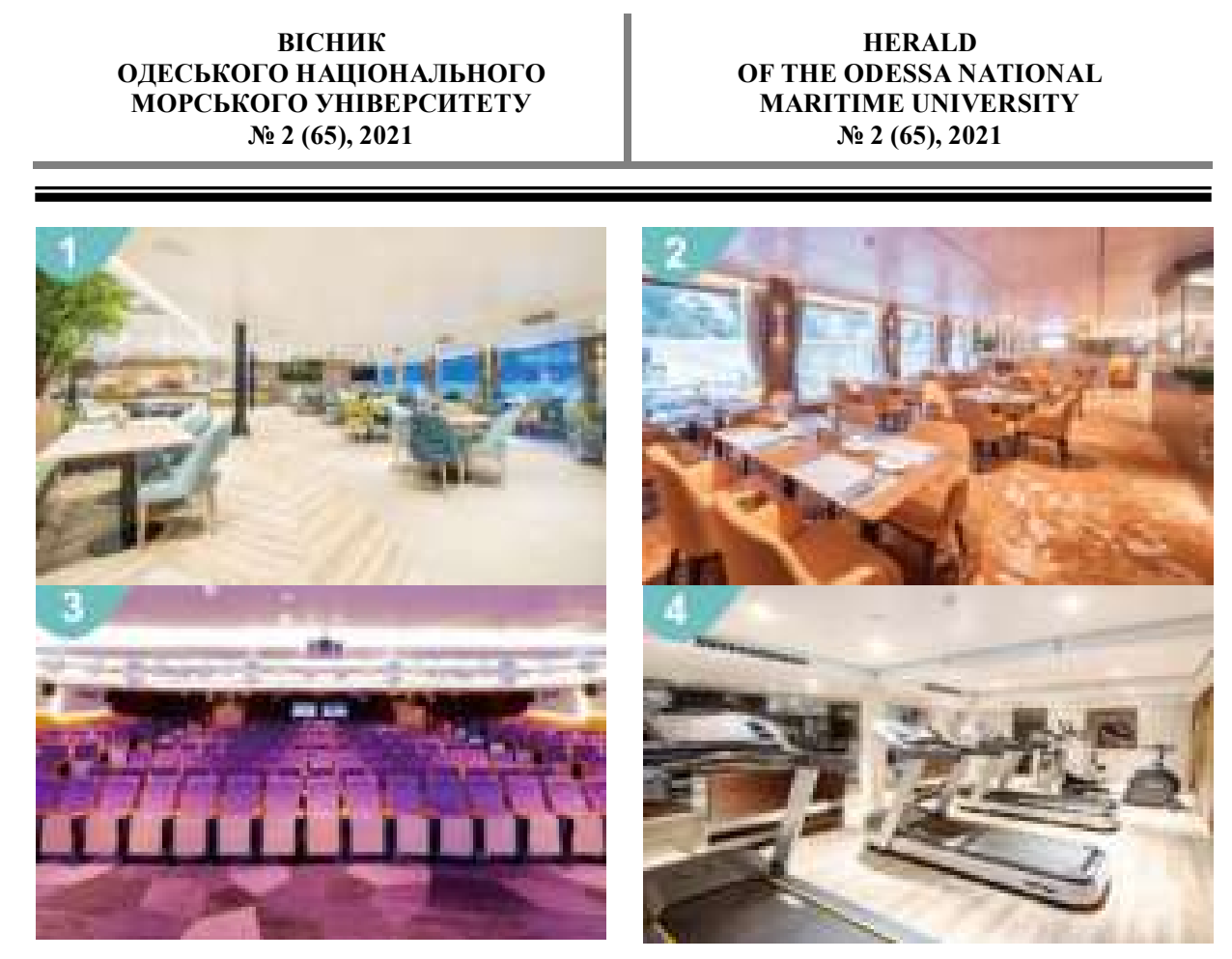

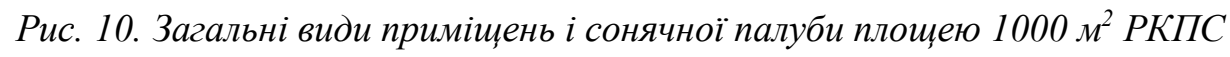
«Century Glory»:

1 - Ресторан «Globe»; 2 - Ресторан «Pavillion»; 3 - Tеатр «Cепtury»; 4 - Фітнес-иентр

Джерело: [10]

Круїзна компанія «Victoria Cruises». Сдина американська круїзна компанія на річці Янцзи 3 власним флотом, одна 3 найбільших круїзних компаній. Флот компанії складається 38 РКПС міжнародного рівня. Останне РКПС компанії «Victoria Sabrina» було здано в експлуатацію в 2020 році (загальний вигляд див. рисунок 12, план палуб - рисунок 13). Інші круїзні судна компанія регулярно модернізує, оновлюється інтер'єр [10].

Всі РКПС компанії працюють 3 «в'їзними» туристами, рівень сервісу відповідає європейським $5 *$. На борту суден «Victoria Cruises» читають лекції про історію та культуру КНР, проходять курси каліграфії та тайцзи (китайської гімнастики) [4].

Судно з гвинто-рульовими колонками, на електрорусі. балконами.

Площа кают на суднах компанії наведена в таблиці 4. Всі каюти 3

Загальний вигляд стандартної каюти на суднах типу «Victoria Sabrina» наведено на рисунку 14, люксу - на рисунку 15. Дизайн кают європейський з включенням китайських елементів. 


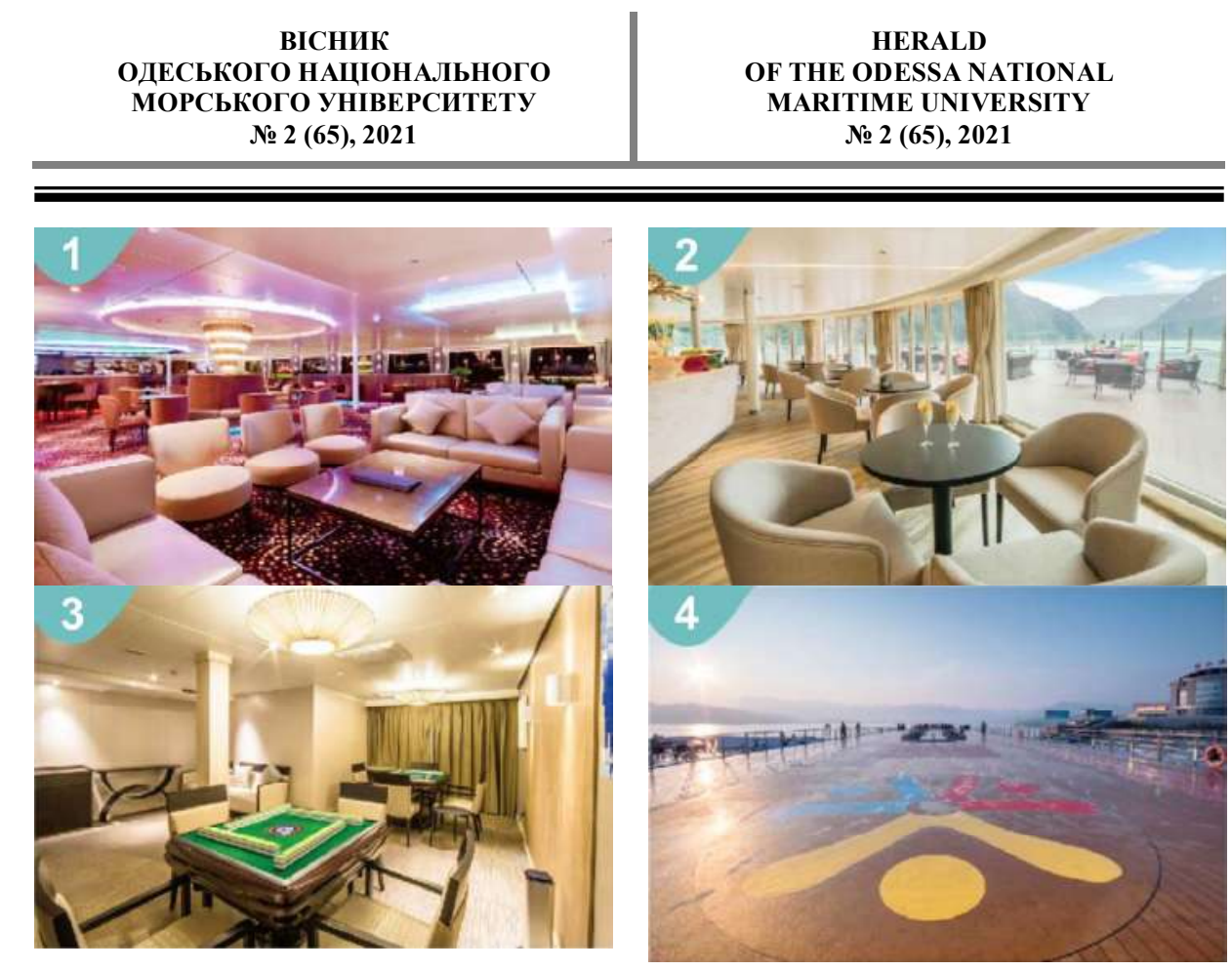

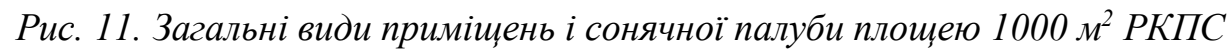
«Century Glory»:

1 - Бар «Cheеrs»; 2 - Kaфе «Панорама»;

3 - Зал для гри в маджонг; 4 - Сонячна палуба

Джерело: [10]

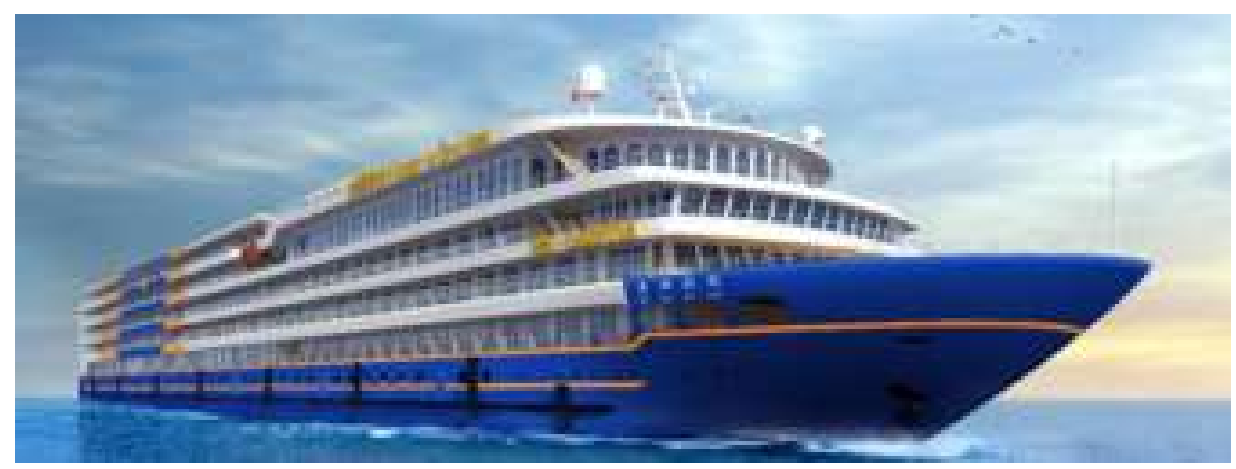

Рис. 12. Загальний вигляд РКПС «Victoria Sabrina» 2020 року будівниитва

Джерело: [10] 
ВІСНИК

ОДЕСЬКОГО НАЦІОНАЛЬНОГО

МОРСЬКОГО УНІВЕРСИТЕТУ № 2 (65), 2021
HERALD

OF THE ODESSA NATIONAL

MARITIME UNIVERSITY № 2 (65), 2021

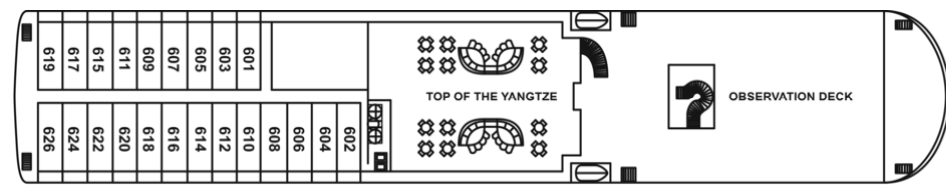

Pinnackle

Deck

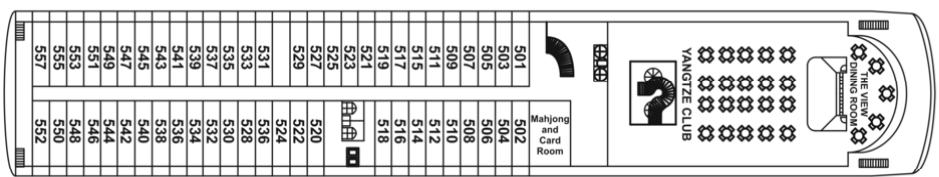

Observation Deck

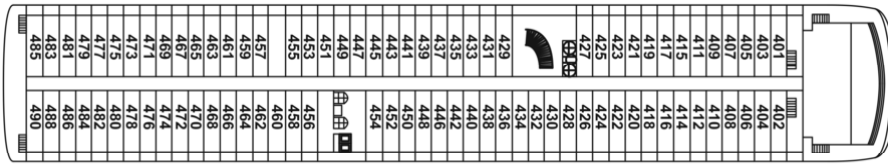

Bridge

Deck

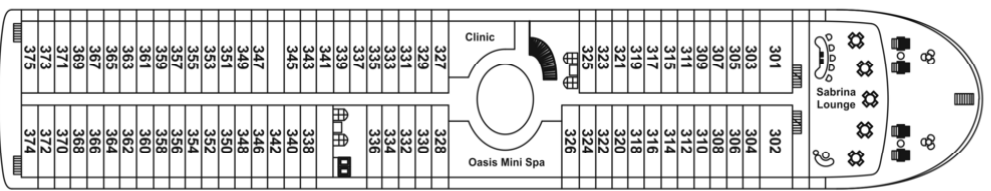

Promenade

Deck
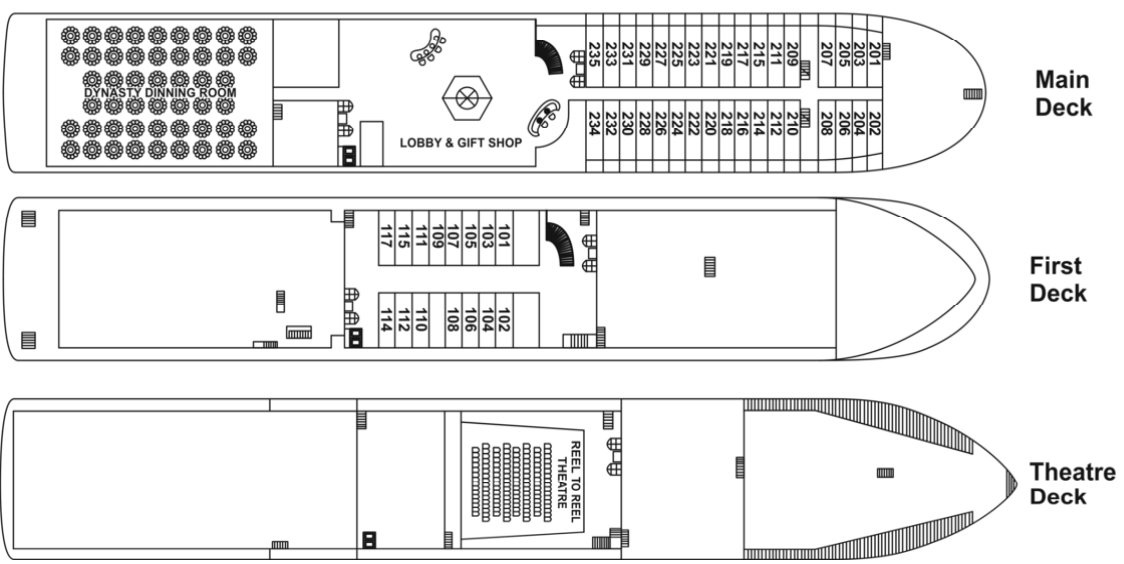

Рис. 13. План палуб РКПС «Victoria Sabrina» 2020 року будівнищтва

Джерело: $[10]$

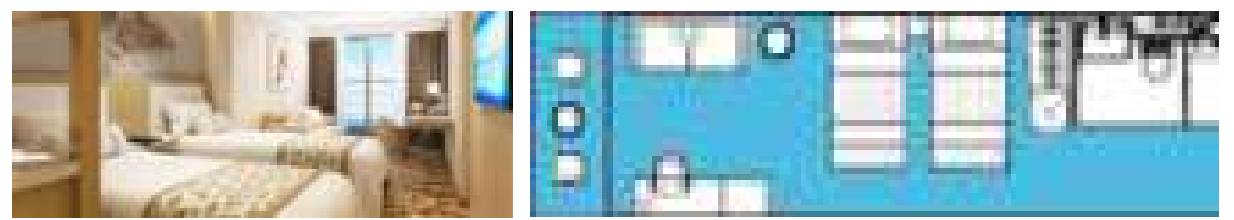

Рис. 14. Стандартна каюта на «Victoria Sabrina»

Джерело: [10] 


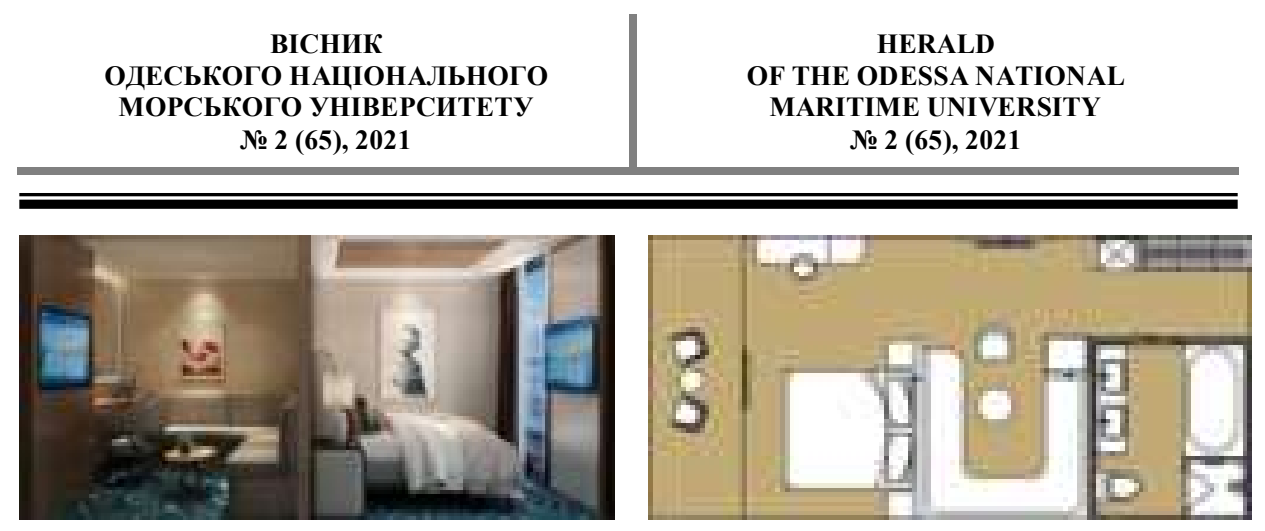

Pис. 15. Каюта класу «люкс» на «Victoria Sabrina»

Джерело: [10]

Табличяя 4

Площуа кают на суднах компанії «Victoria Cruises»

\begin{tabular}{|l|c|c|c|c|}
\hline \multicolumn{1}{|c|}{ Назва судна } & $\begin{array}{c}\text { Кількість } \\
\text { стандартних } \\
\text { кают, од. }\end{array}$ & $\begin{array}{c}\text { Площа } \\
\text { стандартних } \\
\text { кают, } \mathrm{m}^{2}\end{array}$ & $\begin{array}{c}\text { Кількість } \\
\text { кают класу } \\
\text { «Люкс», од. }\end{array}$ & $\begin{array}{c}\text { Площа кают } \\
\text { класу } \\
\text { «Люкс», } \mathrm{m}^{2}\end{array}$ \\
\hline Victoria Sabrina & 262 & 25,5 & 24 & $35,5-51$ \\
\hline Victoria Jenna & 149 & 20,9 & 40 & $31-54,6$ \\
\hline Victoria Anna & 89 & 21,0 & 44 & $29,7-58,8$ \\
\hline Victoria Katarina & 98 & 19,1 & 34 & $30,4-60$ \\
\hline Victoria Lianna & 100 & 19,6 & 8 & $27,3-57,8$ \\
\hline Victoria Selina & 100 & 19,6 & 8 & $27,3-57,8$ \\
\hline Victoria Sophia & 89 & 19,6 & 11 & $27,3-57,8$ \\
\hline Victoria Grace & 88 & 14,6 & 8 & $22-36,9$ \\
\hline
\end{tabular}

Джерело: [10]

Всього на судні 3 ресторани (див. рисунок 16), 1 лаунж-бар, міні спа-зона, $3 \mathrm{~d}$ кінотеатр.

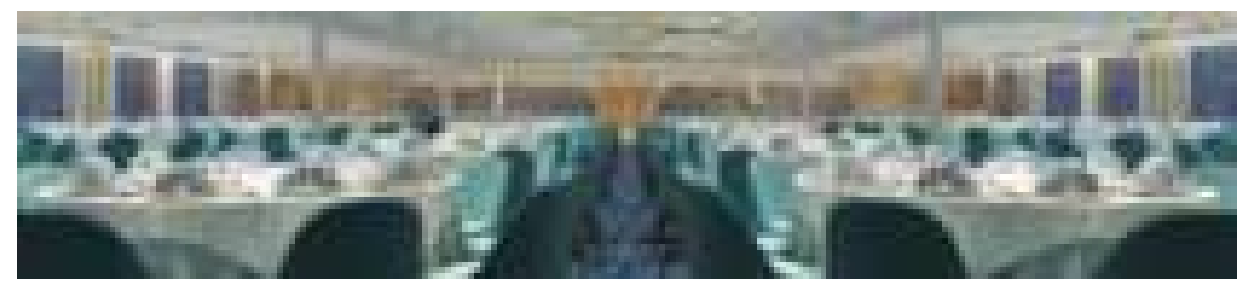

Рис. 16. Основний ресторан на РКПС «Victoria Sabrina»

Джерело: [4]

Загальний вигляд лобі та рецепції на РКПС «Victoria Sabrina» наведені на рисунку 17.

Загальні види приміщень і сонячної палуби РКПС «Victoria Sabrina» наведені на рисунку 18. 


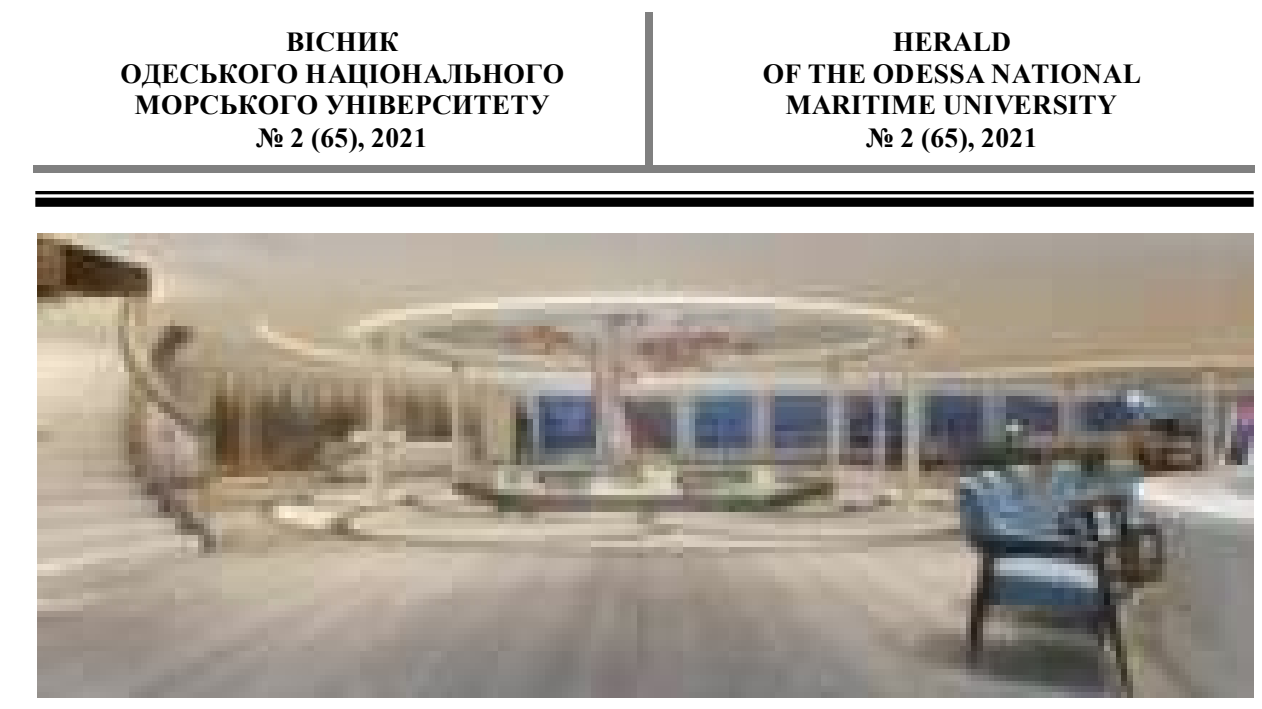

Рис. 17. Лобі та рещееичія на РКПС «Victoria Sabrina»

Джерело: [4]
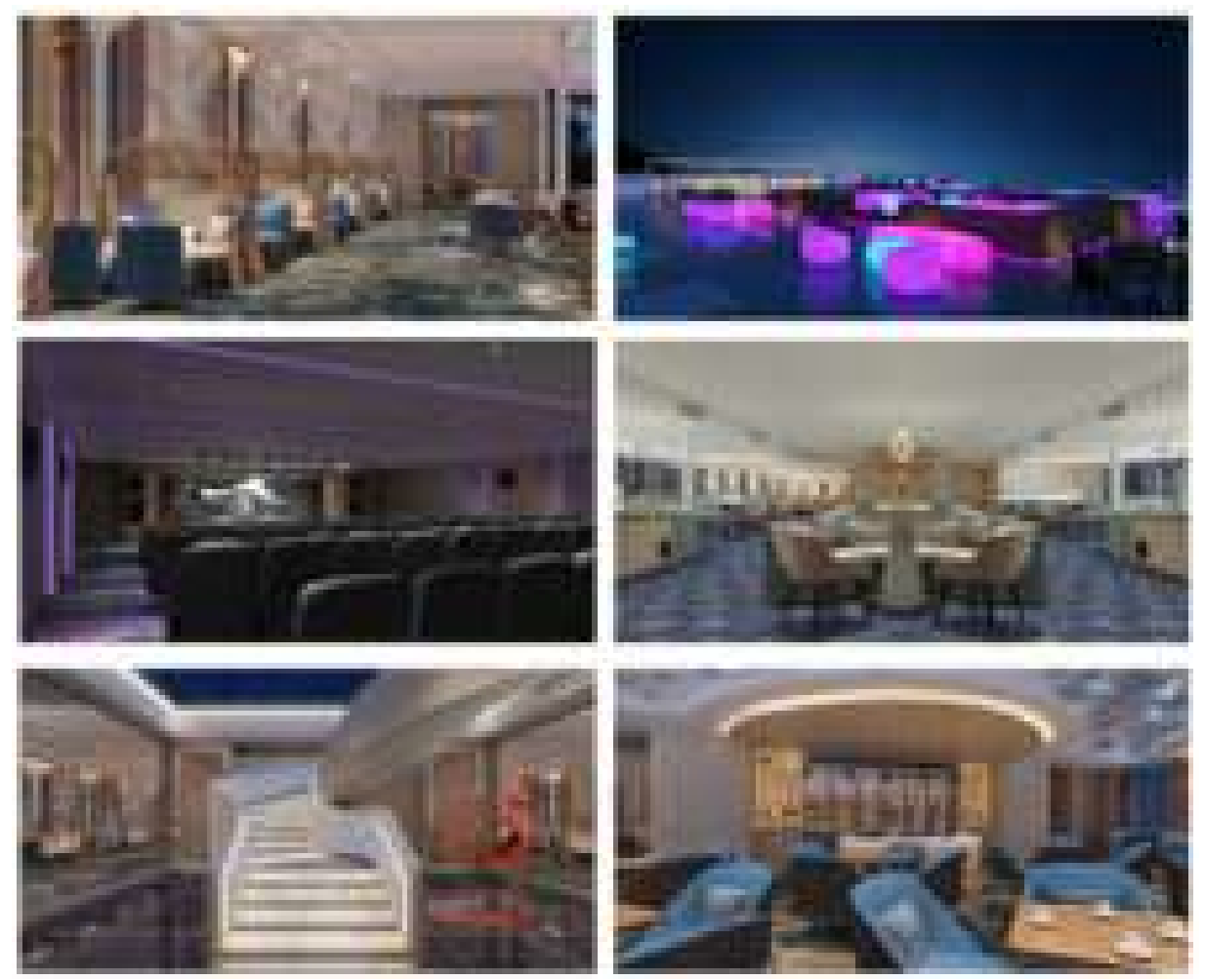

Рис. 18. Загальні види приміщень і сонячної палуби РКПС «Victoria Sabrina»

Джерело: [4] 
Круїзна компанія «Yangtze Gold Cruises». Флот компанії складається 37 РКПС міжнародного рівня. Усі судна побудовані у 2011-2013 роках. Вартість будівництва одного РКПС склала на той момент 130-180 млн. юанів (20,6-28,5 млн. доларів США) [11]. «Yangtze Gold Cruises» планує будівництво нових РКПС ультра-люксового сегмента [14].

На момент будівництва в 2012-2013 роках РКПС компанії «Yangtze Gold 2», «Yangtze Gold 3», «Yangtze Gold 5», «Yangtze Gold 6» були найбільшими річковими суднами на річці Янцзи (загальний вигляд див. рисунок 19, план палуб - рисунок 20). План палуб РКПС типу «Yangtze Gold 1» («Yangtze Gold 7», «Yangtze Gold 8») наведено на рисунку 21.

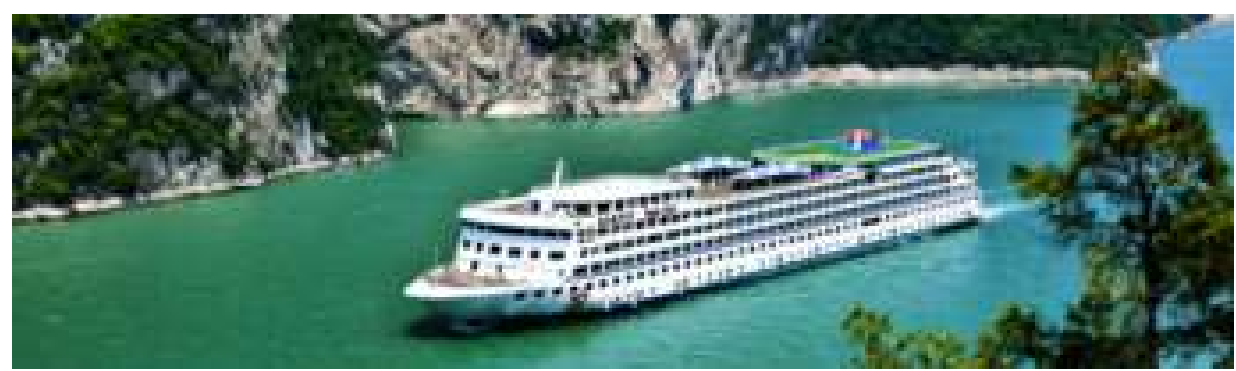

Рис. 19. Загальний вигляд РКПС «Yangtze Gold 2» 2012 року будівниитва

Джерело: [11]

Рівень сервісу на всіх РКПС відповідає європейським 5*. Передбачені внутрішні пішохідні вулиці (площа понад $800 \mathrm{~m}^{2}$ ) з магазинами, вертолітний майданчик, поле для гри в міні-гольф, декілька басейнів відкритого та закритого типу, більярдна [11].

Площа кают на суднах компанії наведена в таблиці 5. Всі каюти, крім внутрішніх, з балконами.

Загальний вигляд стандартної каюти на суднах типу «Yangtze Gold 2» наведено на рисунку 22, люксу - на рисунку 23. Загальний вигляд стандартної каюти на судні «Yangtze Gold 8» наведено на рисунку 24, люксу - на рисунку 25. Дизайн кают східний.

Загальний вигляд основного ресторану на РКПС типу «Yangtze Gold 2» наведено на рисунку 26.

Загальний вигляд лобі та рецепції на РКПС типу «Yangtze Gold 2» наведено на рисунку 27.

Загальні види приміщень і сонячної палуби РКПС типу «Yangtze Gold 2» наведені на рисунку 28, РКПС типу «Yangtze Gold 1» на рисунку 29. 
ВІСНИК

ОДЕСЬКОГО НАЦІОНАЛЬНОГО

МОРСЬКОГО УНІВЕРСИТЕТУ
HERALD

OF THE ODESSA NATIONAL

MARITIME UNIVERSITY № 2 (65), 2021

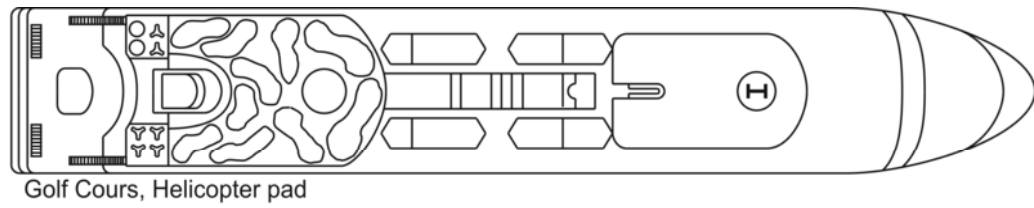

Deck 7
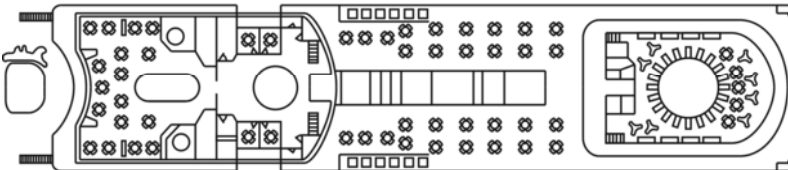

Deck 6

VIP Dining Room, Sun Bar, Barbecue Bar

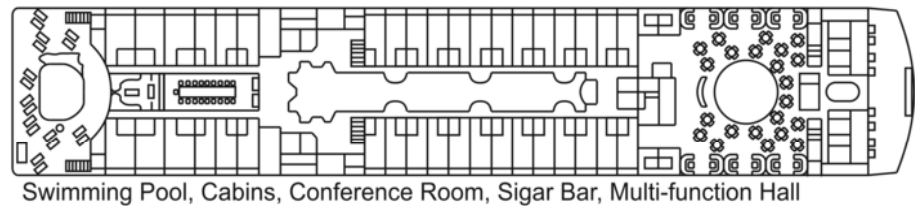

Deck 5

Swimming Pool, Cabins, Conference Room, Sigar Bar, Multi-function Hall

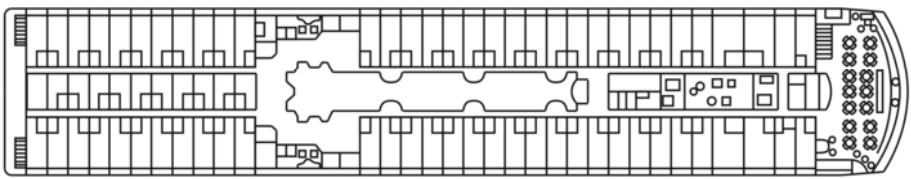

Deck 4

Cabins, Observation Lounge

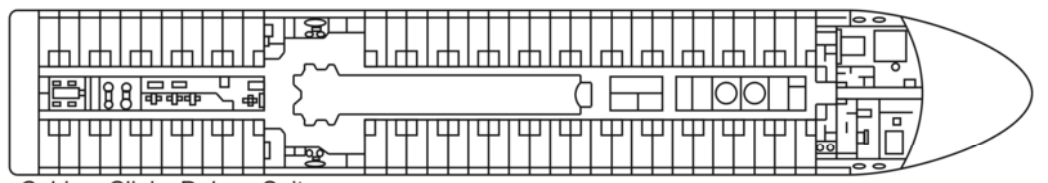

Deck 3

Cabins, Clinic, Deluxe Suite

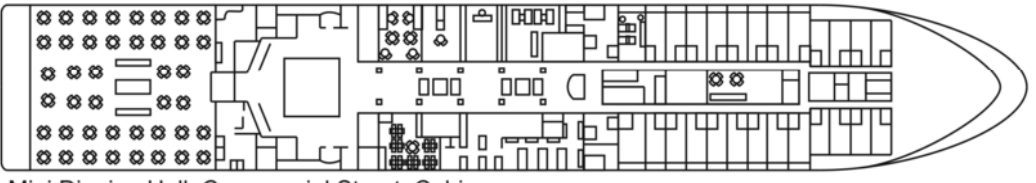

Deck 2

ini Dinning Hall, Commercial Street, Cabins

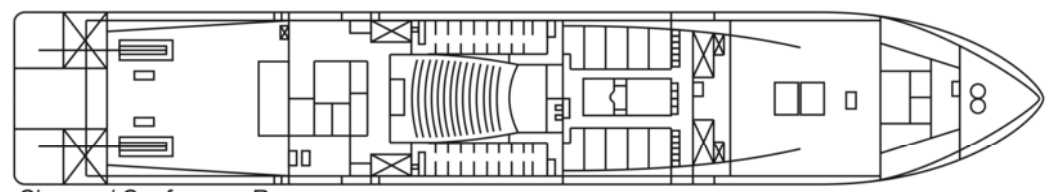

Deck 1

Cinema / Conference Room

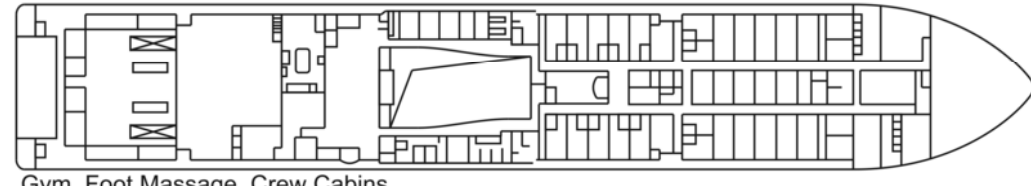

Deck 1

Gym, Foot Massage, Crew Cabins

Рис. 20. План палуб РКПС «Yangtze Gold 2» 2012 року будівництва

Дюерело: [4] 
ВІСНИК

ОДЕСЬКОГО НАЦІОНАЛЬНОГО

МОРСЬКОГО УНІВЕРСИТЕТУ № 2 (65), 2021
HERALD

OF THE ODESSA NATIONAL

MARITIME UNIVERSITY № 2 (65), 2021
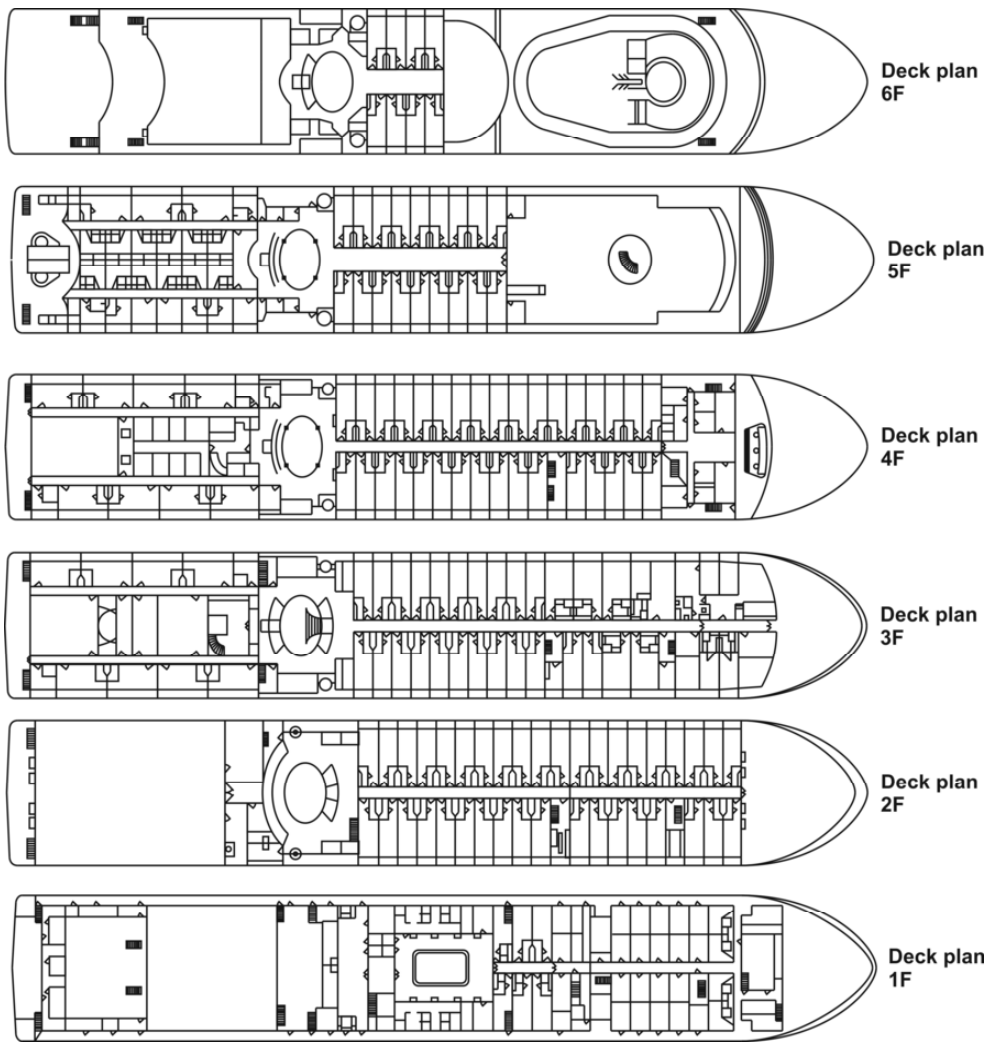

Рис. 21. План палуб РКПС «Yangtze Gold 8» 2013 року будівництва Джерело: [11]
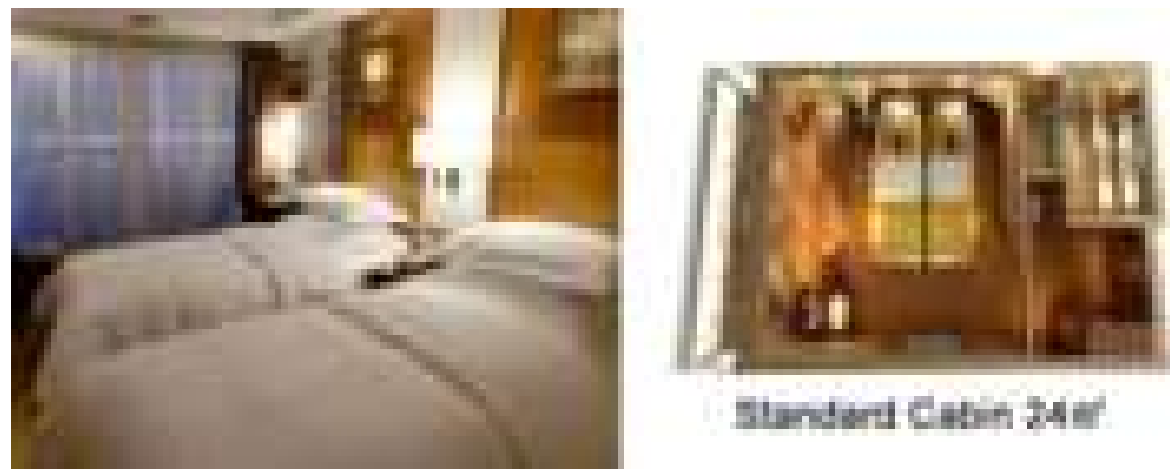

\section{Findaritaingut}

Pис. 22. Стандартна каюта на «Yangtze Gold 2»

Джерело: [4] 


\begin{tabular}{c|c} 
ВІСНИК & HERALD \\
ОДЕСЬКОГО НАЦІОНАЛЬНОГО & OF THE ODESSA NATIONAL \\
МОРСЬКОГО УНІВЕРСИТЕТУ & MARITIME UNIVERSITY \\
№ $2(65), 2021$ & № 2 (65), 2021 \\
\hline
\end{tabular}
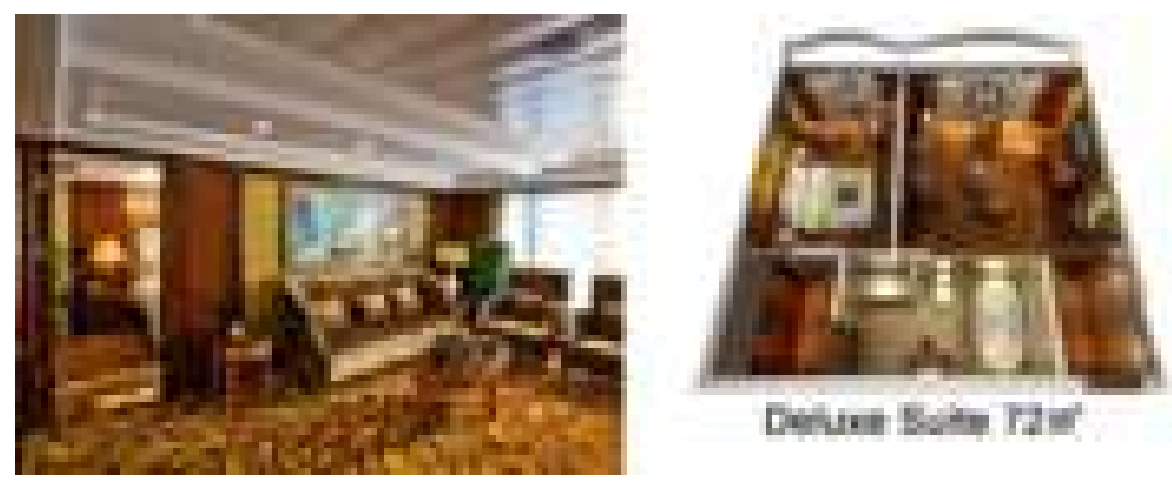

Derum Euth Her

Puc. 23. Каюта класу «люкс» на «Yangtze Gold 2»

Джерело: [4]
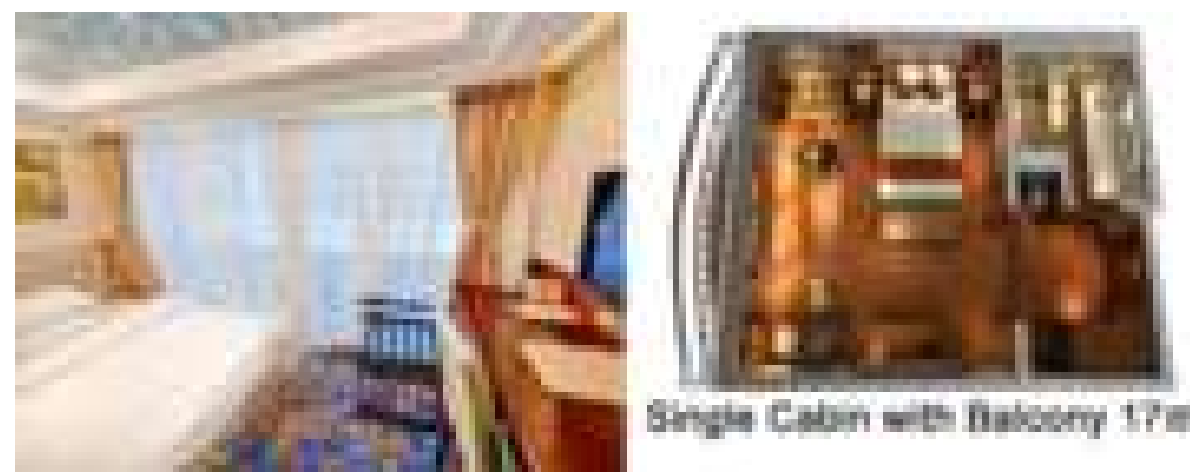

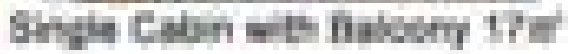

Pис. 24. Стандартна одномісна каюта на «Yangtze Gold 8»

Джерело: [4]
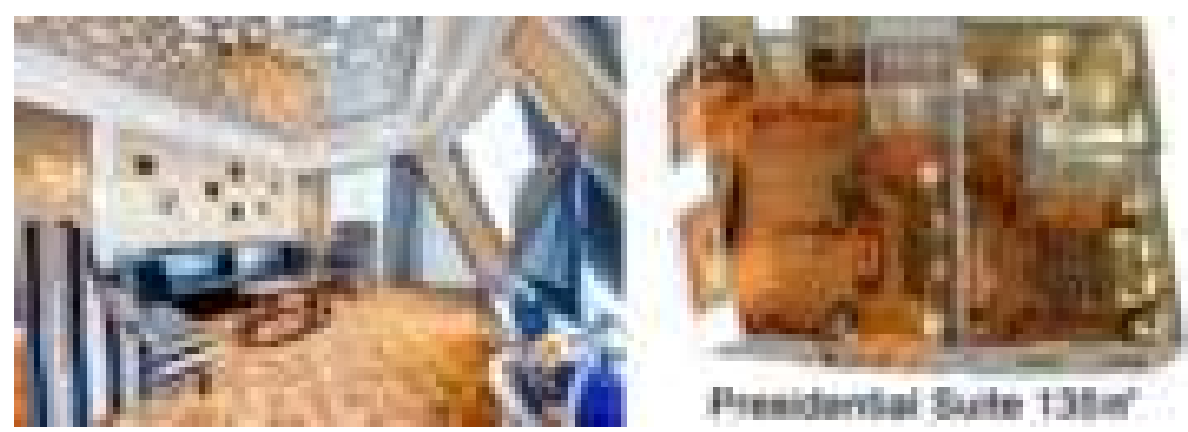

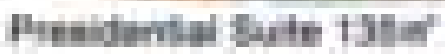

Puс. 25. Каюта класу «Президентський люкс» на «Yangtze Gold 8» Джерело: [4] 


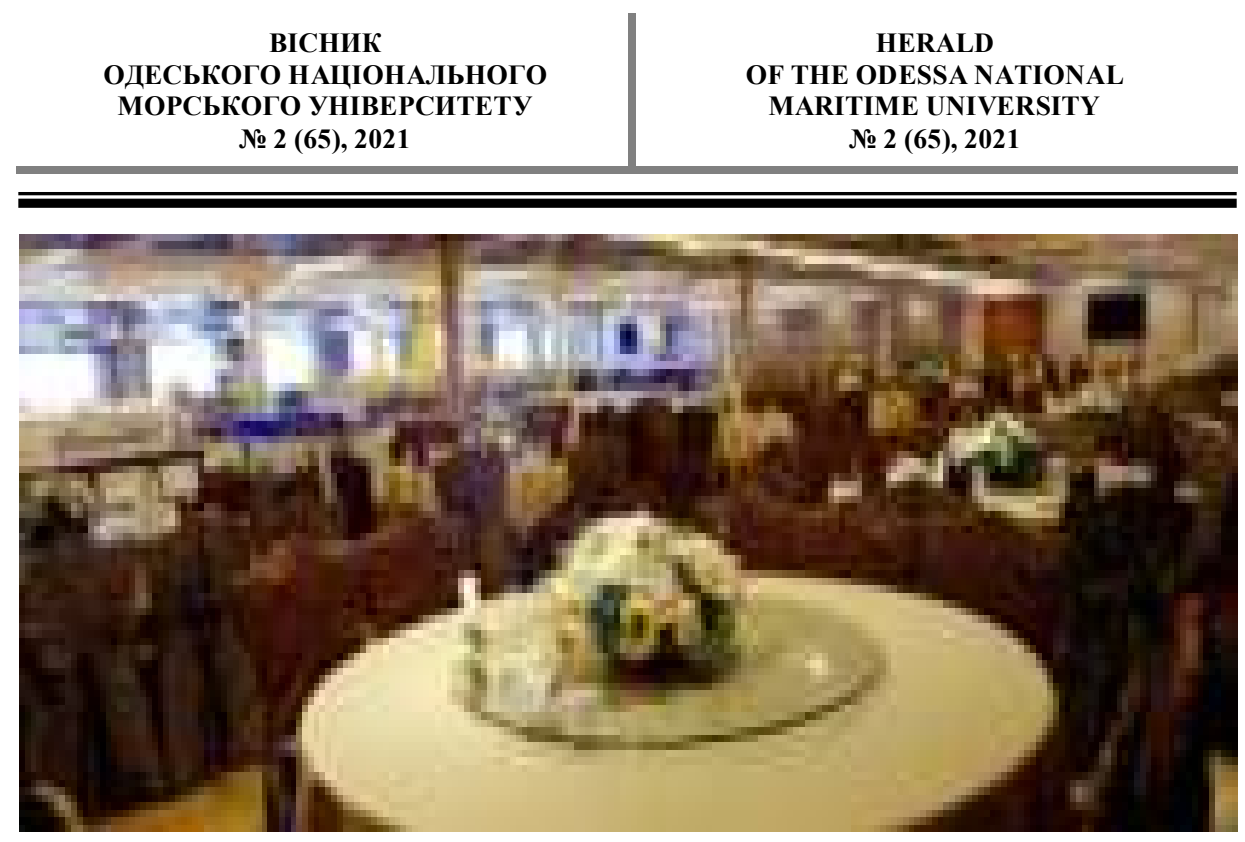

Pис. 26. Основний ресторан на РКПС «Yangtze Gold 2»

Джерело: [4]

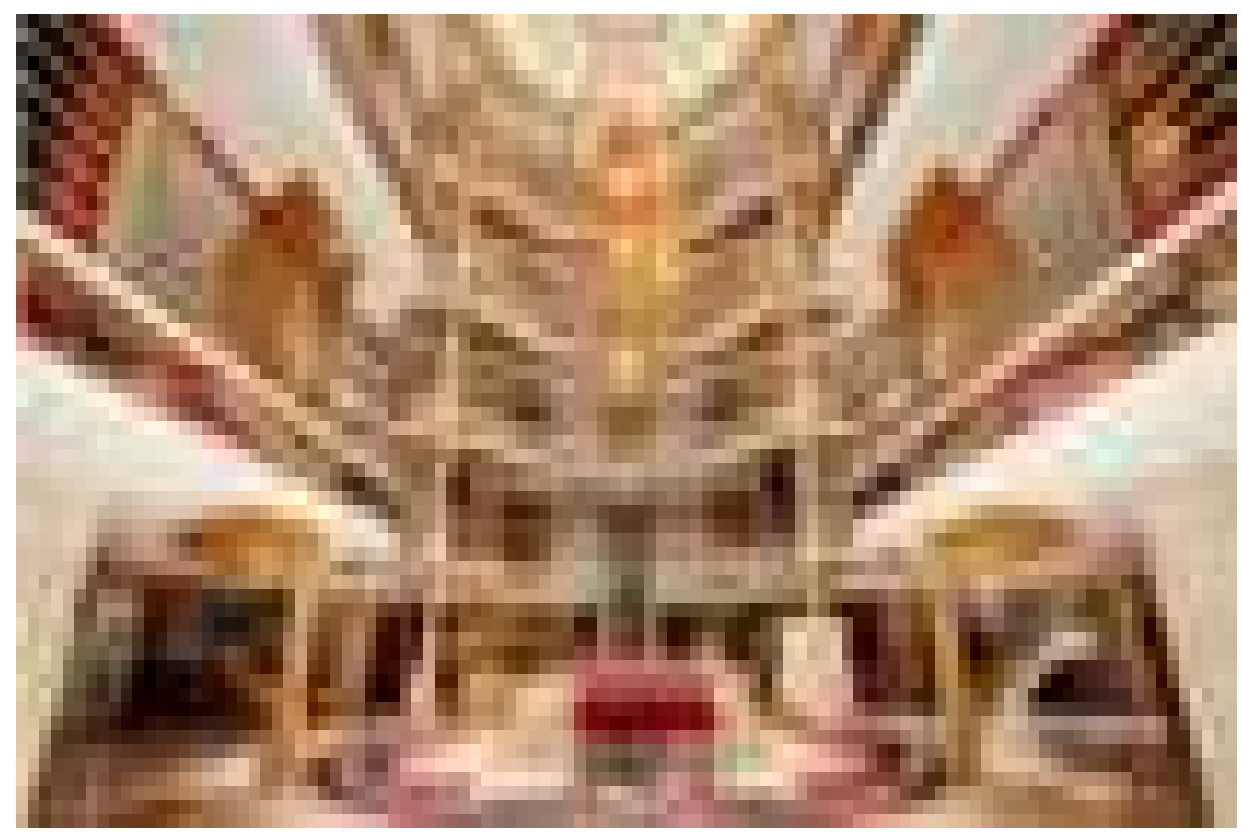

Рис. 27. Лобі та реиепиія на РКПС muny «Yangtze Gold 2»

Джерело: [11] 
ВІСНИК

ОДЕСЬКОГО НАЦІОНАЛЬНОГО

МОРСЬКОГО УНІВЕРСИТЕТУ

№ 2 (65), 2021
HERALD

OF THE ODESSA NATIONAL

MARITIME UNIVERSITY № 2 (65), 2021
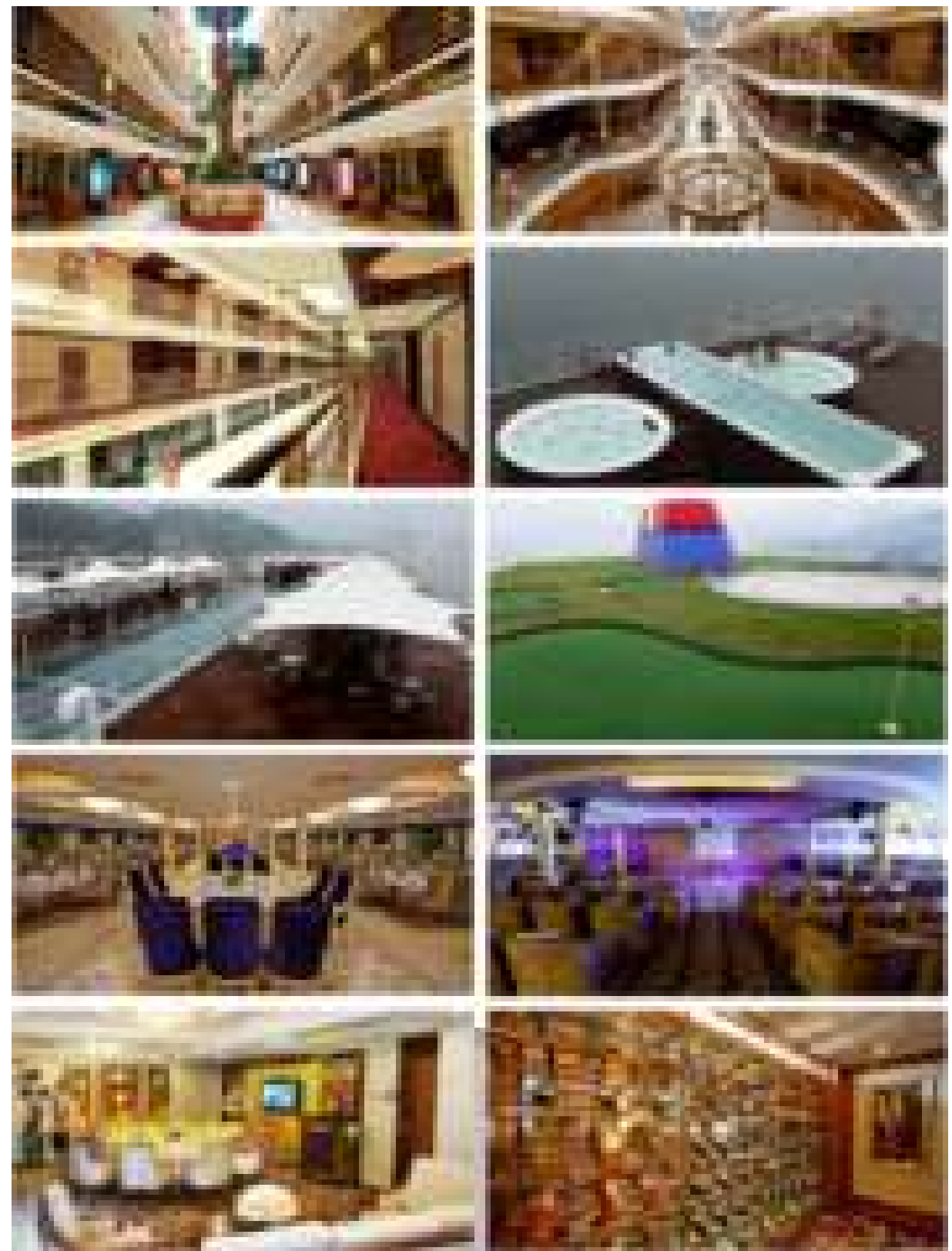

Рис. 28. Загальні види приміщень і сонячної палуби РКПС muny «Yangtze Gold 2»

Джерело: [4] 
ВІСНИК

ОДЕСЬКОГО НАЦІОНАЛЬНОГО

МОРСЬКОГО УНІВЕРСИТЕТУ

№ 2 (65), 2021
HERALD

OF THE ODESSA NATIONAL

MARITIME UNIVERSITY № 2 (65), 2021
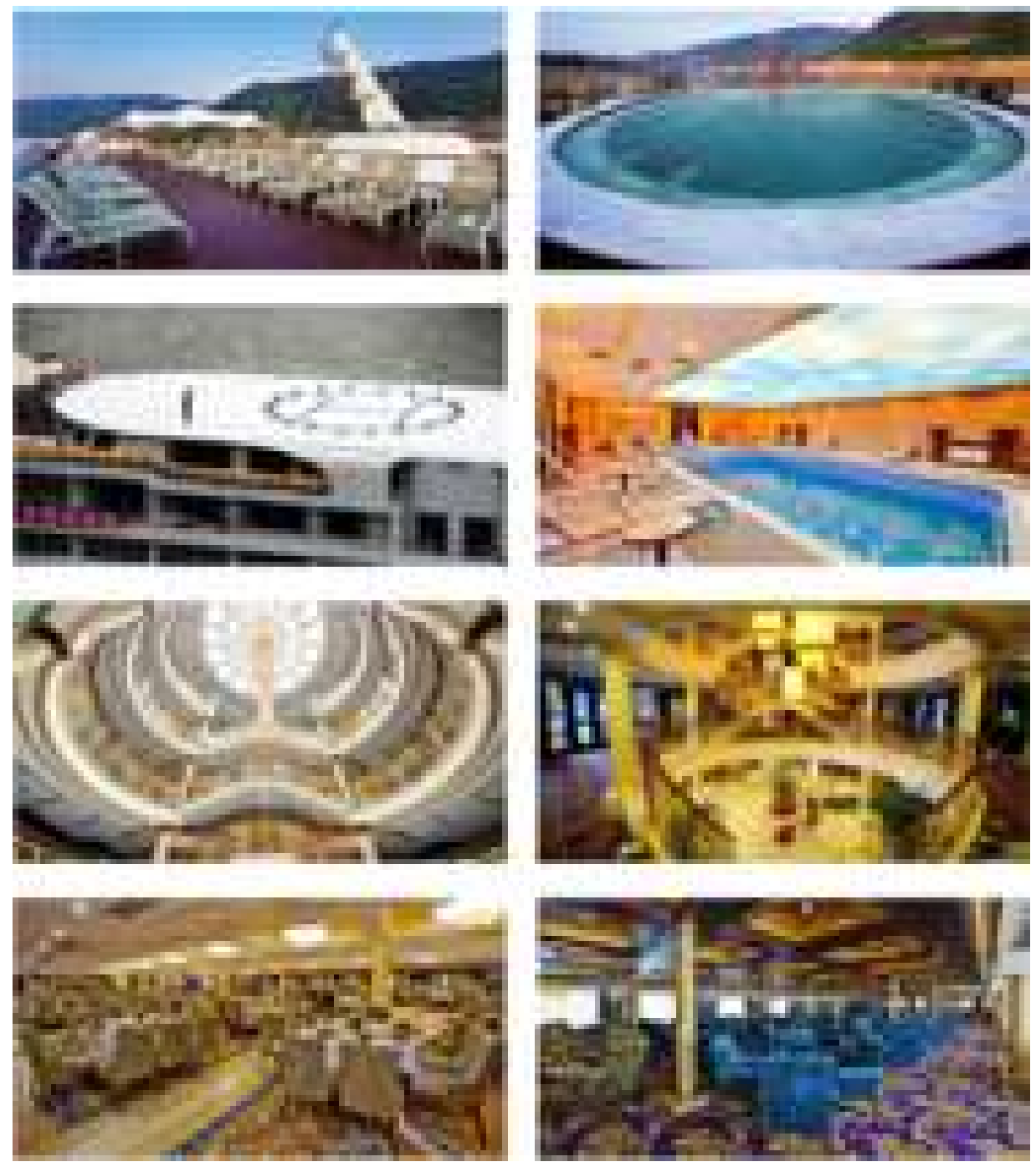

Рис. 29. Загальні види приміщень і сонячної палуби РКПС muny «Yangtze Gold 1»

Джерело: [4]

Круїзна компанія «Sanctuary Yangzi Explorer». Володіє 1 РКПС «Yangtze Explorer» ультра-люкс сегменту - єдине судно такого рівня на річці Янцзи. Судно 2008 року будівництва, в 2016 році було модернізовано. Співвідношення кількості пасажирів до кількості обслуговуючого персоналу 1 до 1. Головна особливість судна - розвинена SPA-зона [12]. 
ВІСНИК

ОДЕСЬКОГО НАЦІОНАЛЬНОГО

МОРСЬКОГО УНІВЕРСИТЕТУ

№ 2 (65), 2021
HERALD

OF THE ODESSA NATIONAL

MARITIME UNIVERSITY № 2 (65), 2021

Загальний вигляд наведено на рисунку 30, план палуб на рисунку 31.

Таблиия 5

Площуа кают на суднах компанї «Yangtze Gold Cruises»

\begin{tabular}{|c|c|c|c|c|}
\hline Назва судна & $\begin{array}{c}\text { Кількість } \\
\text { стандартних } \\
\text { кают, од. }\end{array}$ & $\begin{array}{c}\text { Площа } \\
\text { стандартних } \\
\text { кают, } \text { м }^{2}\end{array}$ & $\begin{array}{c}\text { Кількість } \\
\text { кают класу } \\
\text { «Люкс», од. }\end{array}$ & $\begin{array}{c}\text { Площа кают } \\
\text { класу «Люкс», } \\
\mathbf{M}^{2}\end{array}$ \\
\hline Yangtze Gold 8 & 138 & $15-27$ & 31 & $35-135$ \\
\hline Yangtze Gold 7 & 131 & $15-24$ & 29 & $40-135$ \\
\hline Yangtze Gold 6 & 193 & $16-24$ & 15 & $36-139$ \\
\hline Yangtze Gold 5 & 193 & $16-24$ & 15 & $36-139$ \\
\hline Yangtze Gold 3 & 193 & $16-24$ & 16 & $36-139$ \\
\hline Yangtze Gold 2 & 193 & $16-24$ & 15 & $36-139$ \\
\hline Yangtze Gold 1 & 106 & 26,5 & 42 & $42-132$ \\
\hline
\end{tabular}

Джерело: [11]

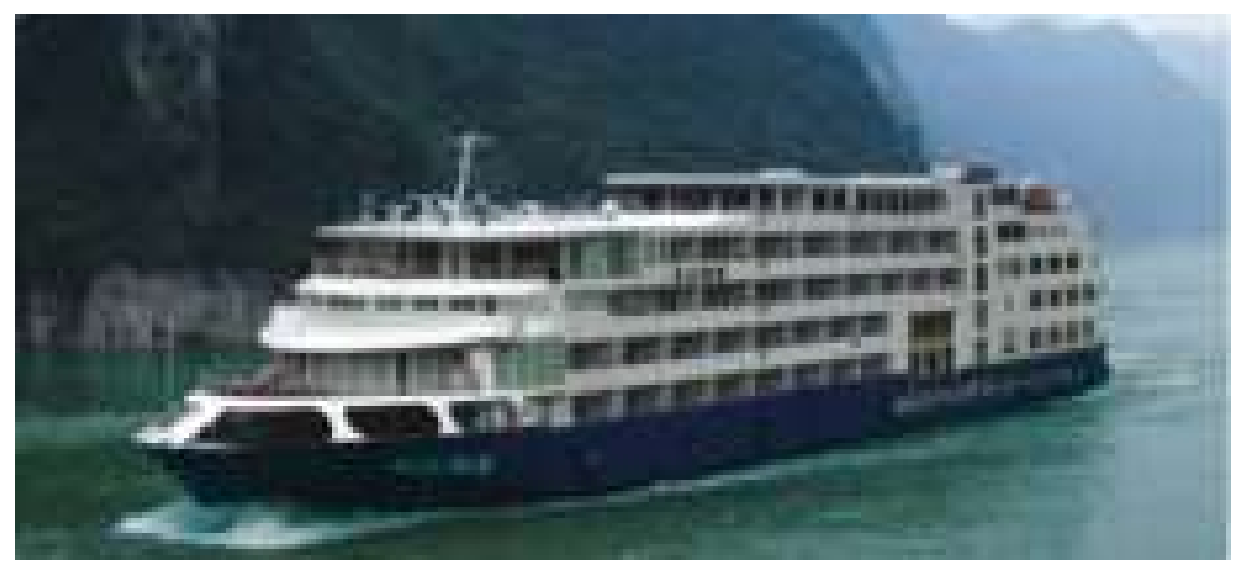

Рис. 30. Загальний вигляд ультра-люксового РКПС «Yangtze Explorer»

\section{Джерело: [15]}

На судні 38 стандартних кают і 24 люкса. Площа стандартних

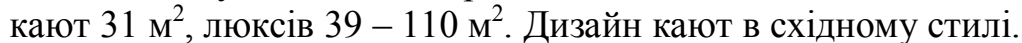

Загальний вигляд стандартної каюти на судні «Yangtze Explorer» наведено на рисунку 32, люксів - на рисунках 33 і 34. 
ВІСНИК

ОДЕСЬКОГО НАЦІОНАЛЬНОГО

МОРСЬКОГО УНІВЕРСИТЕТУ

№ 2 (65), 2021
HERALD

OF THE ODESSA NATIONAL

MARITIME UNIVERSITY № 2 (65), 2021

Загальні види приміщень і сонячної палуби РКПС «Yangtze Explorer» наведено на рисунку 35.
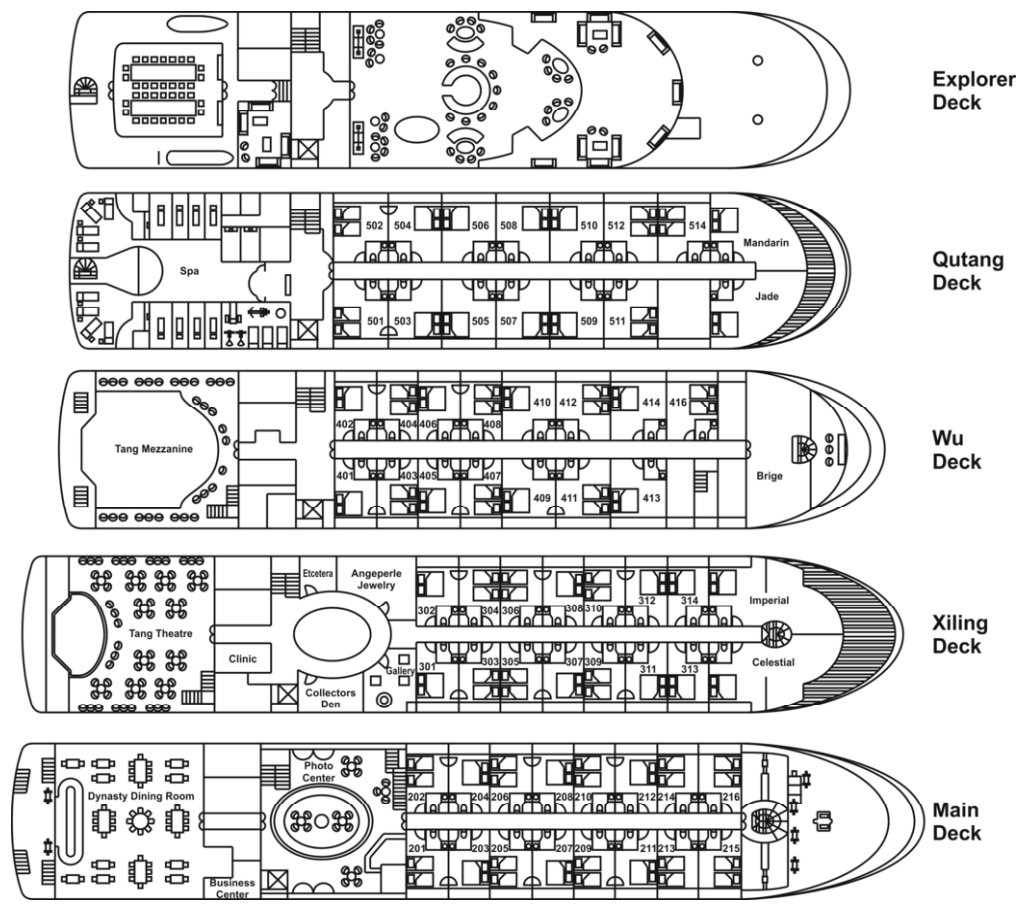

Рис. 31. План палуб ультра-люксового РКПС «Yangtze Explorer»

Джерело: [4]

Круїзна компанія «Changjiang Cruises» (Changjiang Cruise Overseas Travel Cruises). Володіє двома РКПС міжнародного рівня 4 i 5* «Yangtze 1» $\mathrm{i}$ «Yangtze 2». «Yangtze 1»- єдине 3 працюючих РКПС міжнародного рівня, яке може зайти в найбільший в світі суднопідіймач гідровузла «Три ущелини» (габарити суднопідйомника 120 х 18 × 3,5 м), інші РКПС через свої габарити і осадку змушені проходити ділянку шлюзуванням (двонитковий п'ятикамерний шлюз 280 х 34 х 5 м) [4]. Компанія замовила нове РКПС 3 трьома гвинто-рульовими колонками Schottel STP 310 ( $3 \times 1000$ кВт) на електрорусі з метою зниження рівню шуму і вібрації. Очікується, що судно буде здано в експлуатацію в 2021 році (загальний вигляд див. рисунок 36) [13]. балконами.

Площа кают на суднах компанії наведена в таблиці 6. Всі каюти 3

Загальний вигляд стандартної каюти на судні «Yangtze 2» наведено на рисунку 37 , люксу - на рисунку 38. 
ВІСНИК

ОДЕСЬКОГО НАЦІОНАЛЬНОГО

МОРСЬКОГО УНІВЕРСИТЕТУ

№ 2 (65), 2021
HERALD

OF THE ODESSA NATIONAL

MARITIME UNIVERSITY № 2 (65), 2021

Площа кают на суднах компанії наведена в таблиці 6. Всі каюти 3 балконами.

Загальний вигляд стандартної каюти на судні «Yangtze 2» наведено на рисунку 37, люксу - на рисунку 38.
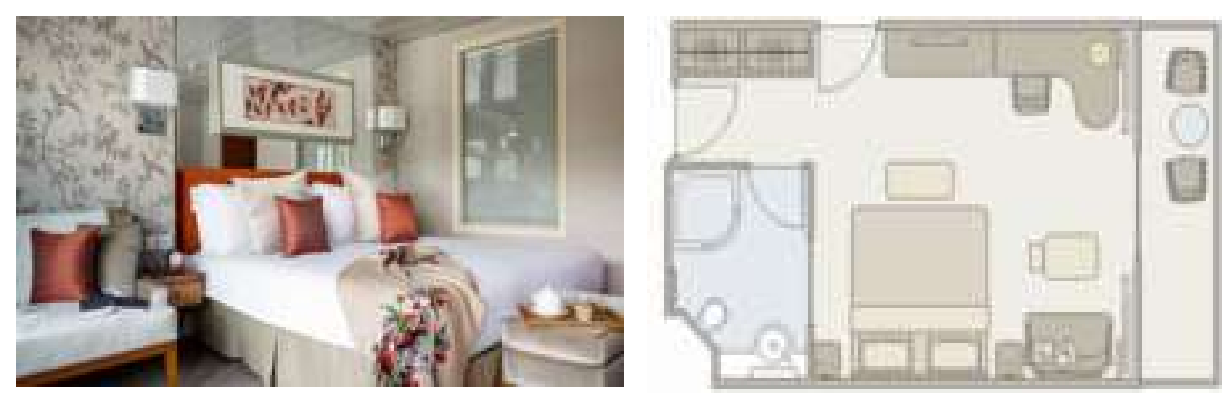

Рис. 32. Стандартна каюта на «Yangtze Explorer»

Джерело: [12]
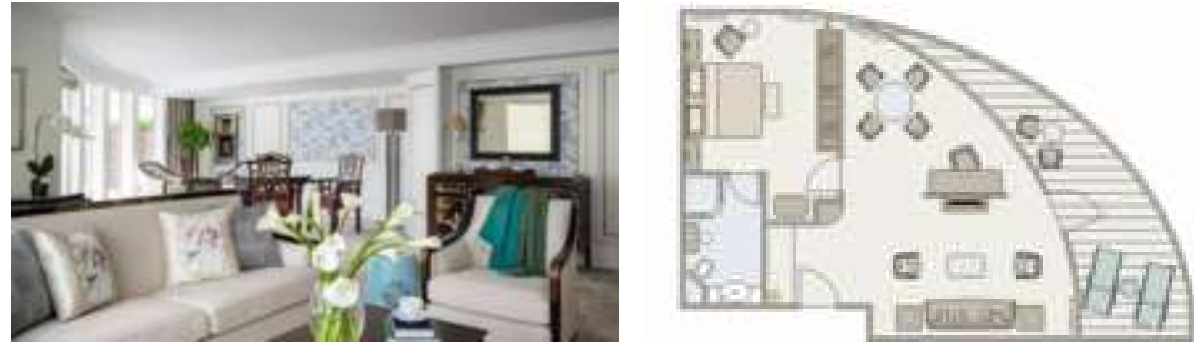

Рис. 33. Каюта класу «Нефритовий люкс» на «Yangtze Explorer»

Джерело: [12]
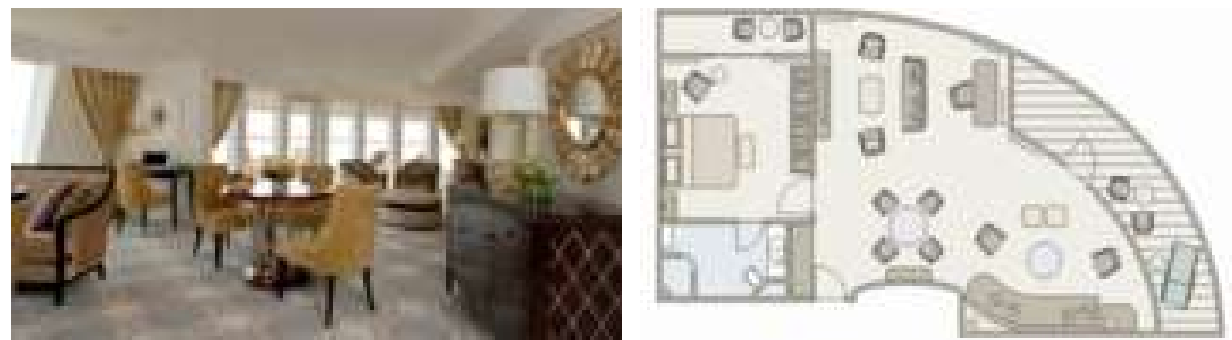

Рис. 34. Каюта класу «Імператорський люкс» на «Yangtze Explorer»

Джерело: [12] 
ВІСНИК

ОДЕСЬКОГО НАЦІОНАЛЬНОГО

МОРСЬКОГО УНІВЕРСИТЕТУ

№ 2 (65), 2021
HERALD

OF THE ODESSA NATIONAL

MARITIME UNIVERSITY

№ 2 (65), 2021
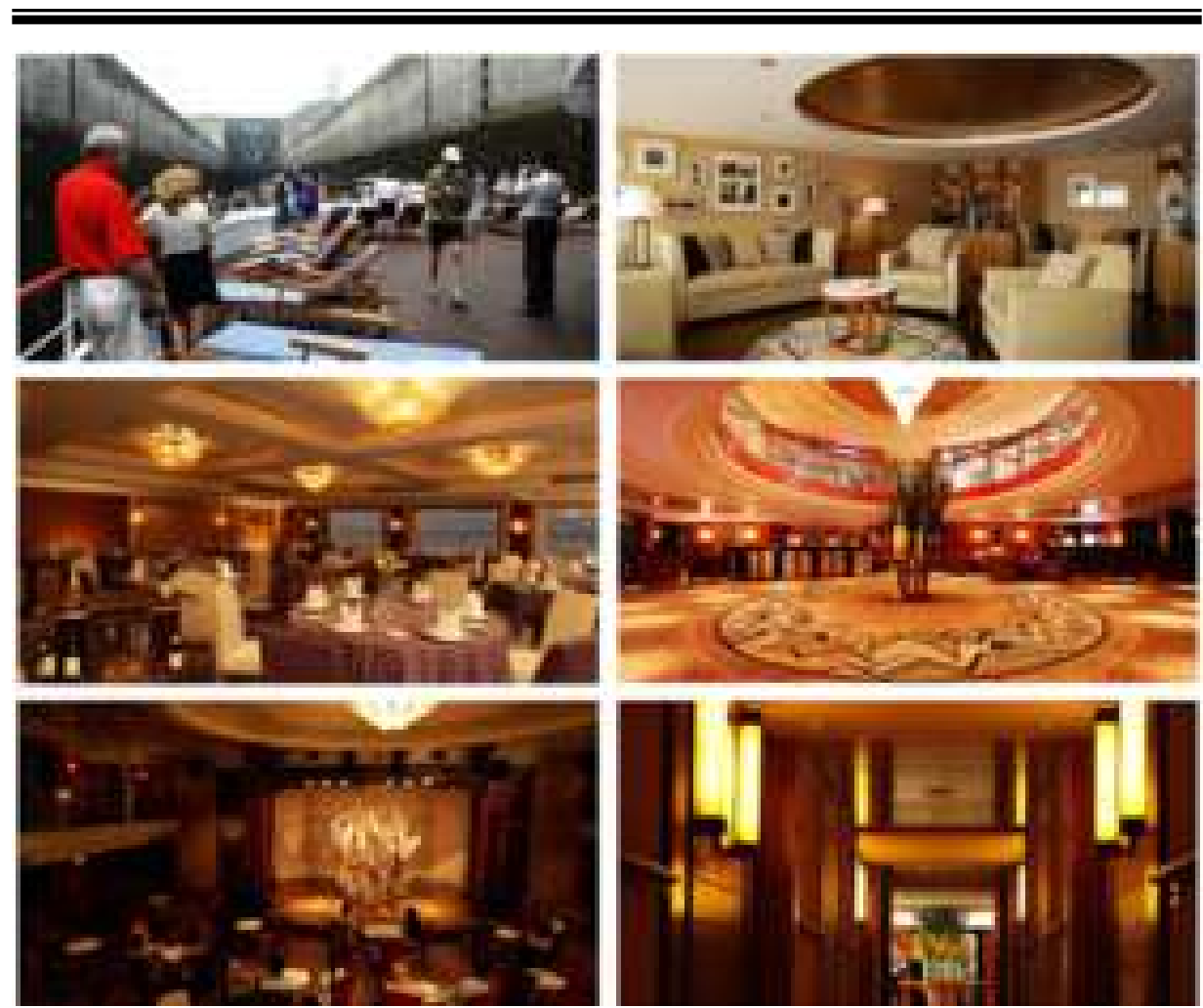

Рис. 35. Загальні види приміщень і сонячної палуби РКПС «Yangtze Explorer»

Джерело: [4]

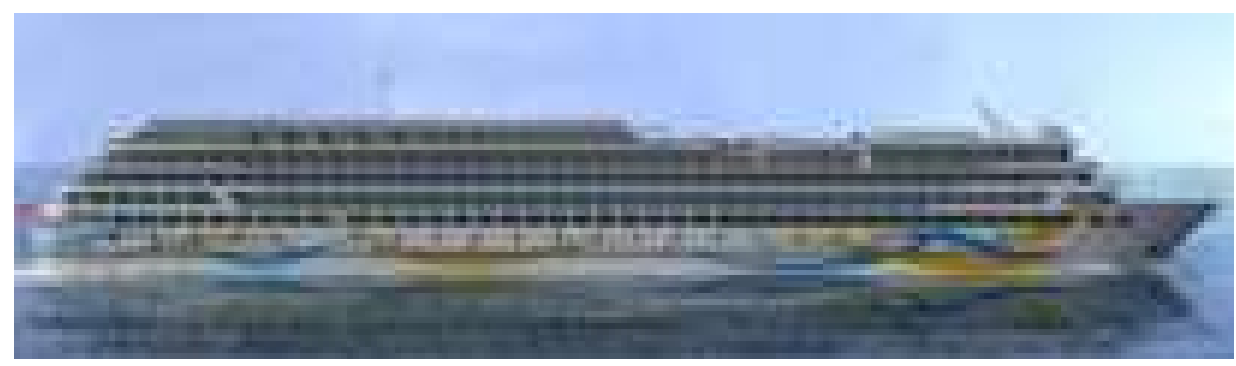

Рис. 36. Загальний вигляд нового РКПС компанії «Changjiang Cruises»

Джерело: [13] 
ВІСНИК

ОДЕСЬКОГО НАЦІОНАЛЬНОГО

МОРСЬКОГО УНІВЕРСИТЕТУ

№ 2 (65), 2021
HERALD

OF THE ODESSA NATIONAL

MARITIME UNIVERSITY № 2 (65), 2021

Таблиия 6

Площа кают на суднах компанії «Changjiang Cruises»

\begin{tabular}{|c|c|c|c|c|}
\hline $\begin{array}{c}\text { Назва } \\
\text { судна }\end{array}$ & $\begin{array}{c}\text { Кількість } \\
\text { стандартних } \\
\text { кают, од. }\end{array}$ & $\begin{array}{c}\text { Площа } \\
\text { стандартних } \\
\text { кают, }{ }^{2}\end{array}$ & $\begin{array}{c}\text { Кількість кают } \\
\text { класу } \\
\text { «Люкс», од. }\end{array}$ & $\begin{array}{c}\text { Площа } \\
\text { кают класу } \\
\text { «Люкс», }{ }^{2}\end{array}$ \\
\hline Yangtze 2 & 156 & 24 & 34 & $36,1-65$ \\
\hline Yangtze 1 & 101 & 14,5 & 8 & $21,6-60$ \\
\hline
\end{tabular}

Джерело: [4]
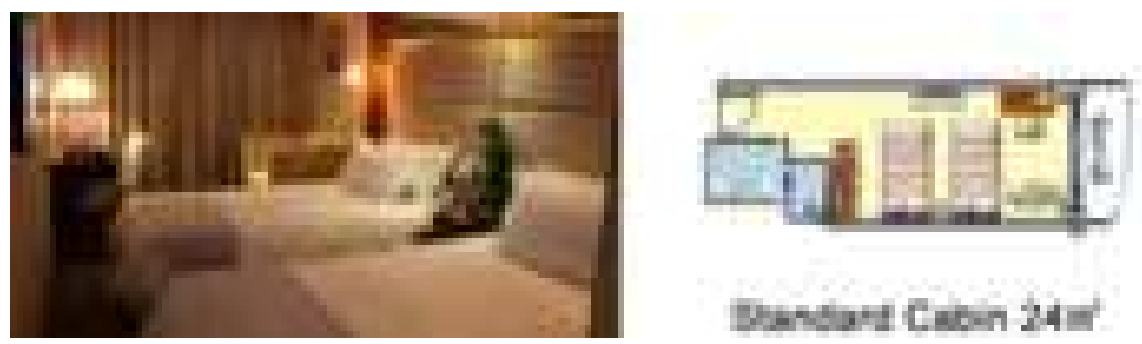

Рис. 37. Стандартна каюта на «Yangtze 2»

Джерело: [4]
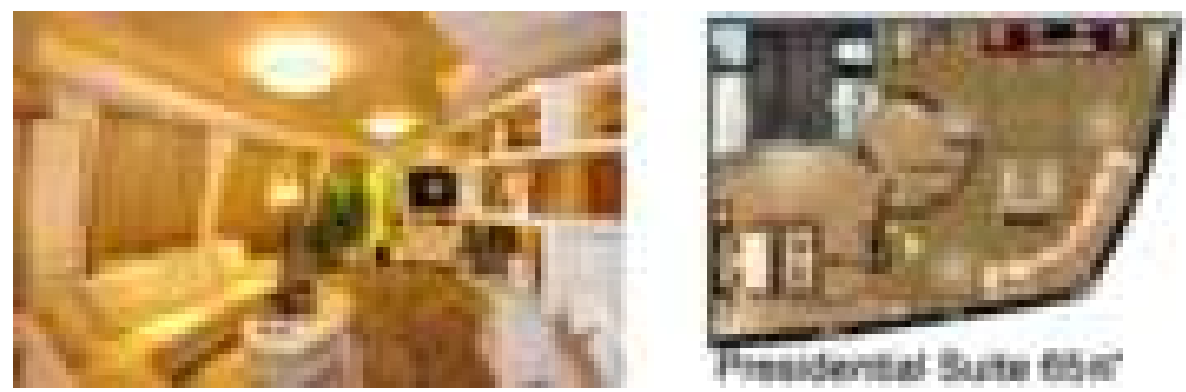

Рис. 38. Каюта класу « Президентський люкс» на «Yangtze 2»

Джерело: [4]

Круїзна компанія «China Goddess Cruises». Володіє трьома РКПС міжнародного рівня 4* «China Goddess 1» і «China Goddess 2». Компанія замовила нове РКПС з трьома гвинтами і 3 кермами «China Goddess $3 »$. Очікується, що судно буде здано в експлуатацію в 2021 році (загальний вигляд див. рисунок 39) [4].

Площа кают на суднах компанії наведена в таблиці 7. Всі каюти з балконами. 


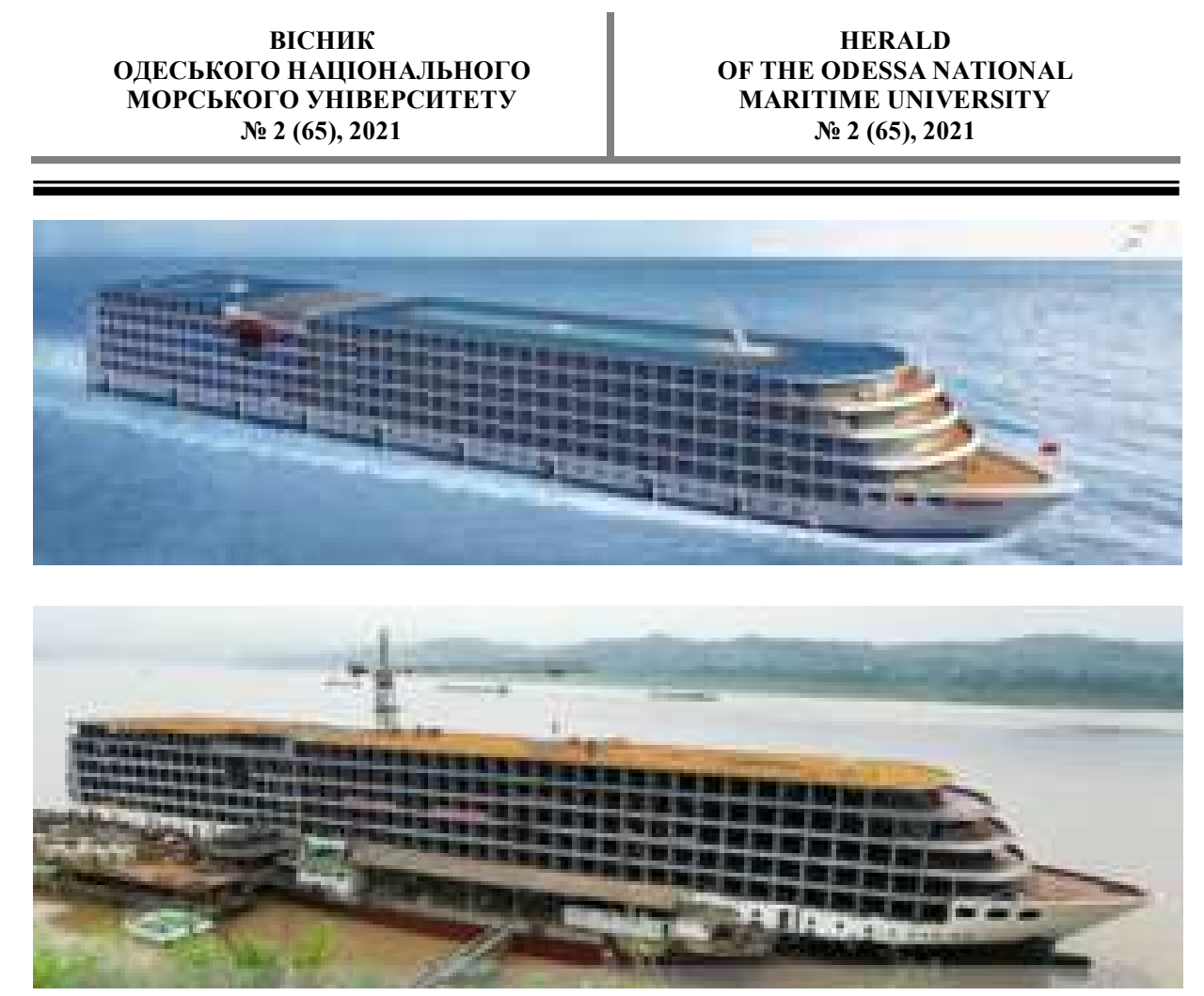

Рис. 39. Загальний вигляд нового РКПС компании «China Goddess Cruises»

Джерело: [4]

Таблиия 7

Площа кают на суднах компанії «China Goddess Cruises»

\begin{tabular}{|c|c|c|c|c|}
\hline Назва судна & $\begin{array}{c}\text { Кількість } \\
\text { стандартних } \\
\text { кают, од. }\end{array}$ & $\begin{array}{c}\text { Площа } \\
\text { стандартних } \\
\text { кают, }{ }^{2}\end{array}$ & $\begin{array}{c}\text { Кількість } \\
\text { кают класу } \\
\text { «Люкс», од. }\end{array}$ & $\begin{array}{c}\text { Площа } \\
\text { кают класу } \\
\text { «Люкс», }{ }^{2}\end{array}$ \\
\hline China Goddess 2 & 143 & 25 & 20 & $35-137$ \\
\hline China Goddess 1 & 113 & 20,1 & 6 & $24,2-101$ \\
\hline
\end{tabular}

\section{Джерело: [4]}

Круїзна компанія «President Cruises» володіє трьома РКПС міжнародного рівня $5^{*}$ «President No.6», «President No.7», «President No.8» (загальний вигляд див. рисунок 40, план палуб - рисунок 41). Всі судна побудовані в 2013 році.

Площа кают на суднах компанії наведена в таблиці 8. Всі каюти 3 балконами. 
ВІСНИК

ОДЕСЬКОГО НАЦІОНАЛЬНОГО

МОРСЬКОГО УНІВЕРСИТЕТУ

№ 2 (65), 2021
HERALD

OF THE ODESSA NATIONAL

MARITIME UNIVERSITY № 2 (65), 2021

Загальний вигляд стандартної каюти на судні «President No.8» наведено на рисунку 42, люксу - на рисунку 43 , президентського люксу на рисунку 44.

Елементи круїзів на стандартних китайських РКПС для місцевих туристів для порівняння 3 РКПС міжнародного рівня наведені на рисунку 45.

Таблиия 8

\section{Площа кают на суднах компанії «President Cruises»}

\begin{tabular}{|c|c|c|c|c|}
\hline Назва судна & $\begin{array}{c}\text { Кількість } \\
\text { стандартних } \\
\text { кают, од. }\end{array}$ & $\begin{array}{c}\text { Площа } \\
\text { стандартних } \\
\text { кают, } \mathrm{m}^{2}\end{array}$ & $\begin{array}{c}\text { Кількість } \\
\text { кают класу } \\
\text { «Люкс», од. }\end{array}$ & $\begin{array}{c}\text { Площа } \\
\text { кают класу } \\
\text { «Люкс», }{ }^{2}\end{array}$ \\
\hline President No. 8 & 215 & 27,5 & 15 & $41,2-114$ \\
\hline President No. 7 & 215 & 27,5 & 15 & $41,2-114$ \\
\hline President No. 6 & 151 & 26,5 & 36 & $39,8-176$ \\
\hline
\end{tabular}

Висновок. Виконане дослідження флоту РКПС показало, що на січень 2021 року в експлуатації на річці Янцзи знаходяться 29 РКПС міжнародного рівня. Ще 6 РКПС добудовуються і будуть здані в 20212023 роках. Середній вік працюючих РКПС 12,1 рік. Сумарна пасажиромісткість 10889 чоловік, з урахуванням суден, які будуть здані в експлуатацію найближчим часом, 14739 чоловік. Середня завантаженість РКПС в 2017 році склала $75-82 \%$.

Вартість будівництва РКПС міжнародного рівня «Century Glory» компанії «Century Cruises» 2019 року побудови склала 300 млн. юанів (46 млн. доларів США).

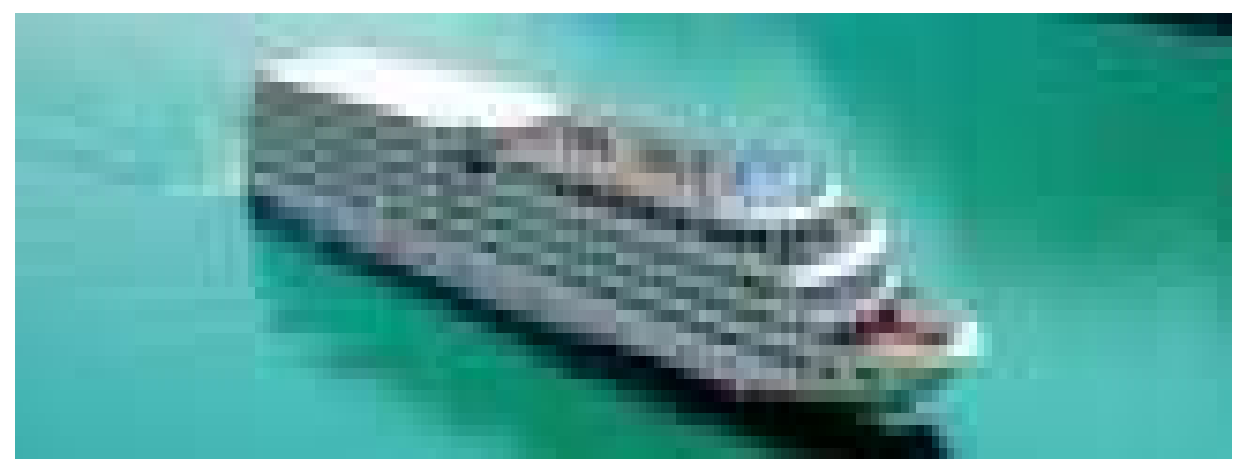

Рис. 40. Загальний вигляд РКПС «President № 8»

Джерело: [4] 
ВІСНИК

ОДЕСЬКОГО НАЦІОНАЛЬНОГО

МОРСЬКОГО УНІВЕРСИТЕТУ
HERALD

OF THE ODESSA NATIONAL

MARITIME UNIVERSITY № 2 (65), 2021
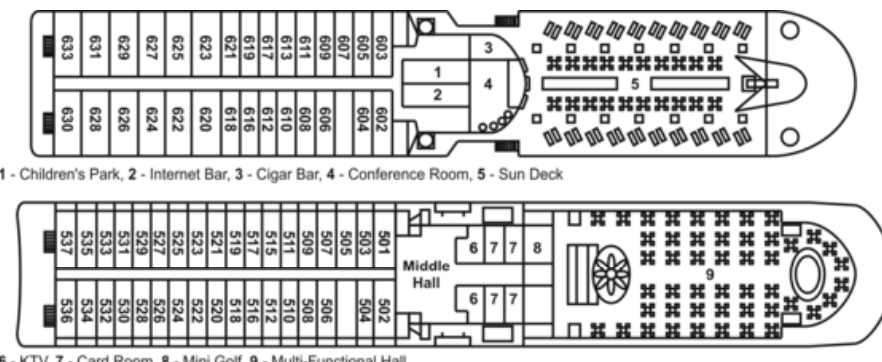

$5 L$

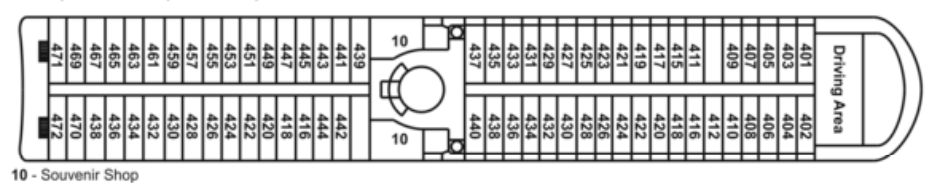

$4 \mathrm{~L}$
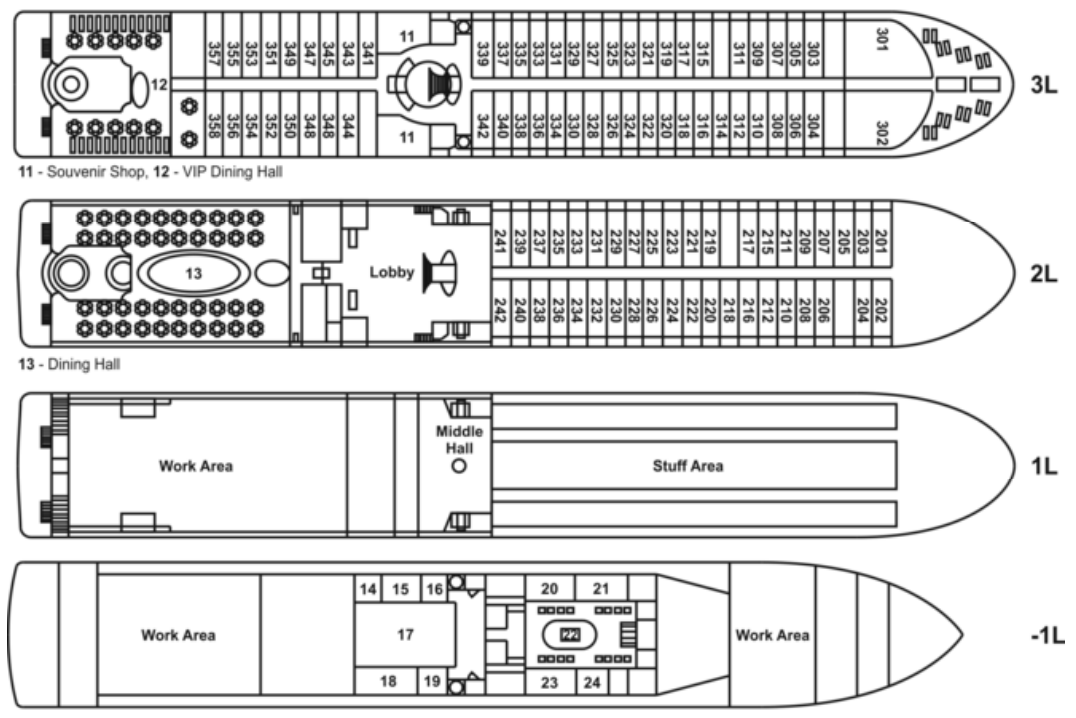

Рис. 41. План палуб РКПС «President № 8»

Джерело: [4]

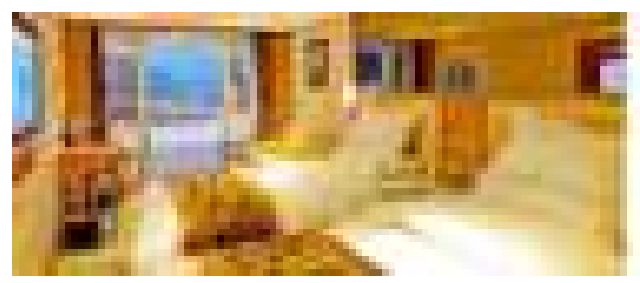

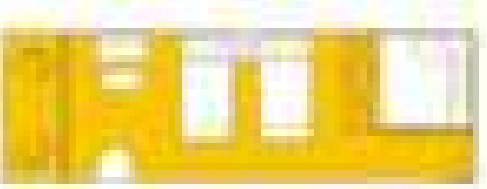

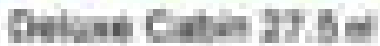

Puc. 42. Стандартна каюта на «President № 8»

Джерело: [4] 


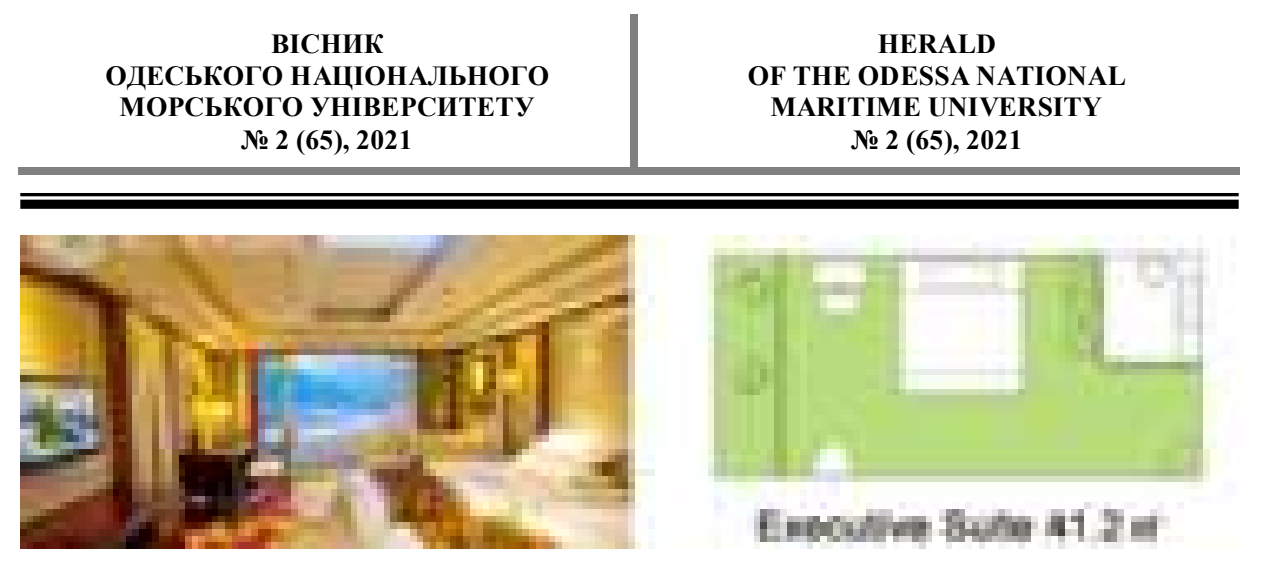

Puc. 43. Каюта класу «люкс» на «President № 8»

Джерело: [4]
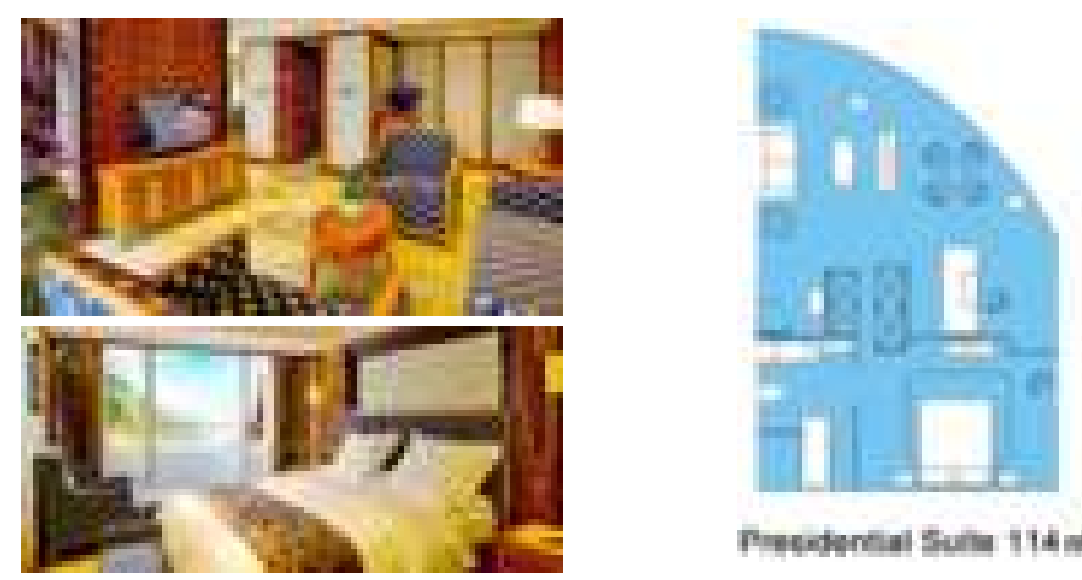

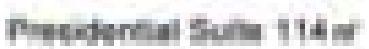

Pис. 44. Каюта класу «Президентський люкс» на «President № 8»

Джерело: [4]

Нові судна для «в'їзних» туристів проектуються і будуються 3 зірковістю 5+*. Враховуються особливості китайського регіону: східні майстер-класи, курси каліграфії, тайцзи і традиційної китайської медицини, окремі віп ресторани і лаунж-зони, кімнати для гри в маджонг, китайське караоке KTV, лекції про історію та культуру КНР, китайські елементи в інтер'єрах. Площа стандартних кают варіюється від 15 до $31 \mathrm{~m}^{2}$ (на єдиному ультра-люксовому китайському РКПС «Yangtze Explorer»),

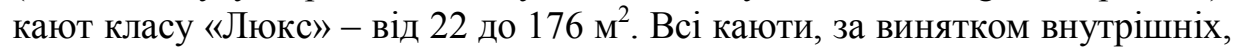
з балконами.

Приділяється особлива увага комфортабельності на борту і екологічності суден: $з$ метою зменшення шуму і вібрації нові РКПС будуються 3 гвинто-рульовими колонками на електрорусі, встановлюються системи очищення стічних вод, відходи переробляються прямо на борту. 


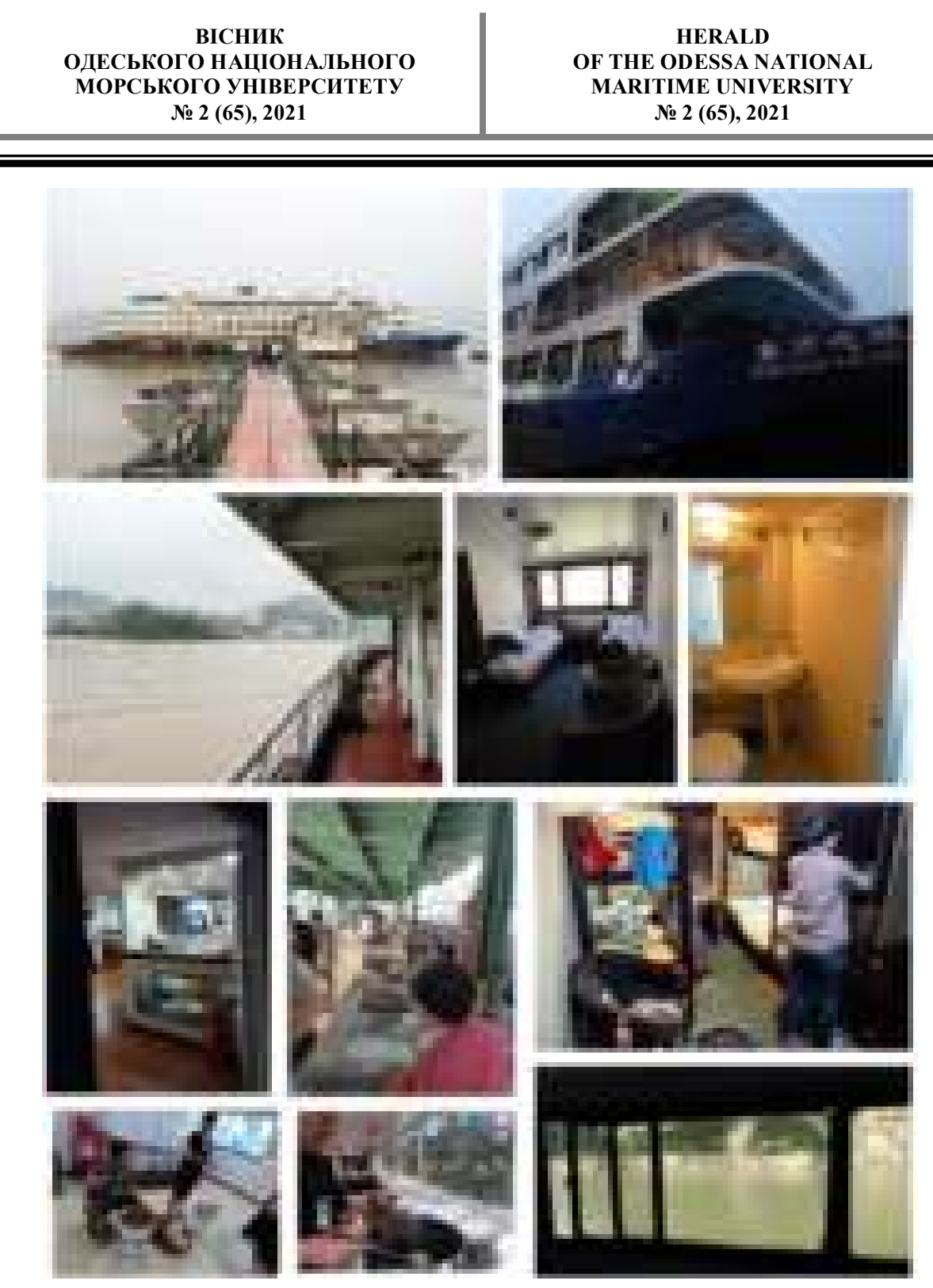

Рис.45. Круїз на стандартних китайських РКПС для місиевих туристів

\section{Джерело: [16; 17]}

За рахунок великого надводного габариту (більше 20 м) кількість палуб на РКПС міжнародного рівня може досягати 7 - а це додаткова корисна площа, яка відображається на функціональності, сервісі і пасажиромісткості таких суден (різноманітні SPA-зони відкритого і закритого типу, двоярусні ресторани і театри, майданчики для міні-гольфу, пішохідні вулиці з магазинами всередині судна, величезні лобі, кількість пасажирів 500-650 чоловік при площах пасажирських кают від 15 м² тощо). 


\section{ЛІТЕРАТУРА}

1. Егоров А.Г. Развитие европейского флота и рынка речных круизов // Морской Вестник. - 2020. -- №3 (75). - C. 21-26.

2. Егоров А.Г. Речные круизные пассажсирские суда: инноваиионные решения и их применимость при конверсии // Вісник ОНМУ. - Одеса: ОНМУ, 2018. - Bun. 4 (57). C. 23-52.

3. Егоров А.Г. Речные круизные суда КНР: исследование применяемых технических решений и особенностей круизов // Морской Вестник. - 2021. - №1 (77). - C. 25-30.

4. Сайт «Yangtze». [Електронний ресурс] - Режим доступу: https://www.yangtze.com/cruise-ships/ (дата звернення 20.01.2021).

5. Caŭm «Century River Cruises». [Електронний ресурс] - Режим docmyny: http://www.centuryrivercruises.com/en/it-cx.html (dama звернення 20.01.2021).

6. Сайm «Cruise and Ferry». [Електронний ресурс] - Режим доcmyny: https://www.cruiseandferry.net/articles/century-cruises-todebut-third-ship-on-yangtze-river (дата звернення 20.01.2021).

7. Caйm «Yangtze». [Електронний ресурс] - Режим доступу: https://www.yangtze.com/cruise-ships/changjiang-cruises/ (Jama звернення 20.01.2021).

8. Cайm «Yangtze». [Електронний ресурс] - Режим доступу: https://www.yangtze.com/cruise-ships/china-goddess-cruises/

(дата звернення 20.01.2021).

9. Сайm «Yangtze». [Електронний ресурс] - Режим доступу: https://www.yangtze.com/cruise-ships/president-cruises) (dama звернення 20.01.2021).

10. Сайm «Victoria Cruises». [Електронний ресурс] - Режим доcmyny: https://www.victoriacruiselines.com/ (дата звернення 20.01.2021).

11. Caüm «Yangtze Gold Cruises». [Електронний ресурс] - Режим docmyny: http://yangtzegoldcruises.com/aspx/en/index.aspx (dama звернення 20.01.2021).

12. Сайm «Sanctuary Retreats». [Електронний ресурс] - Режим docmyny: $\quad$ https://www.sanctuaryretreats.com/china-cruisesyangzi- explorer (дата звернення 20.01.2021).

13. Сайm «Maritime Executive». [Електронний ресурс] - Режим docmyny: https://maritime-executive.com/corporate/schottel-propulsion-for-next-generation-yangtze-cruise-vessel (дата звернення 20.01.2021). 
ВІСНИК

ОДЕСЬКОГО НАЦІОНАЛЬНОГО

МОРСЬКОГО УНІВЕРСИТЕТУ

№ 2 (65), 2021
HERALD

OF THE ODESSA NATIONAL

MARITIME UNIVERSITY

№ 2 (65), 2021

14. Caüm «World Tourism Cities Federation Cruise Brach». [Електронний ресурс] - Режим доступу: http://www. cciwtcf. org/ work/showproduct.php?lang $=$ cn\&id $=258$ (дата звернення 20.01.2021).

15. Caŭm "China Highlights». [Електронний ресурс] - Режим доcmyny: https://www.chinahighlights.com/yangtzecruise/yangziexplorer/ (дата звернення 20.01.2021).

16. Сайm «Borders of Adventure». [Електронний ресурс] - Режим docmyny: https://www.bordersofadventure.com/ yangtze_river_ cruise_local_not_luxury_travel/ (дата звернення 20.01.2021).

17. Caйm «Asocial No Mad». [Електронний ресурс] - Режим docmyny: https://asocialnomad.com/china/yangtze-river-cruisechinese-boat/ (дата звернення 20.01.2021).

\section{REFERENCES}

1. Egorov, A.G. (2020). Razvitiye yevropeyskogo flota i rynka rechnykh kruizov [Development of the European fleet and river cruise market]. Morskoy Vestnik (Maritime Reporter), 3 (75), 21-26 (in Russian).

2. Egorov, A.G. (2018). Rechnyye kruiznyye passazhirskiye suda: innovatsionnyye resheniya $i$ ikh primenimost' pri konversii [River cruise passenger ships: innovative solutions and their applicability for conversion]. Visnuk ONMU (Reporter of Odessa National Maritime University), 4 (57), 23-52 (in Russian).

3. Egorov, A.G. (2021). Rechnyye kruiznyye suda KNR: issledovaniye primenyayemykh tekhnicheskikh resheniy i osobennostey kruizov [China river cruise ships: research of applied technical solutions and cruises' features]. Morskoy Vestnik (Maritime Reporter), 1 (77), 25-30 (in Russian).

4. "Yangtze» website. [Electronic source] - Retrieved from: https:// www.yangtze.com/cruise-ships/ (access date 20.01.2021).

5. «Century River Cruises» website. [Electronic source] - Retrieved from: http://www.centuryrivercruises.com/en/it-cx.html (access date 20.01.2021).

6. "Cruise and Ferry» website. [Electronic source] - Retrieved from: https://www.cruiseandferry.net/articles/century-cruises-to-debutthird-ship-on-yangtze-river (дата обращения 20.01.2021).

7. «Yangtze» website. [Electronic source] - Retrieved from: https:// www.yangtze.com/cruise-ships/changjiang-cruises/ (access date 20.01.2021).

8. «Yangtze» website. [Electronic source] - Retrieved from: https:// www.yangtze.com/cruise-ships/china-goddess-cruises/ (access date 20.01.2021). 
ВІСНИК

ОДЕСЬКОГО НАЦІОНАЛЬНОГО

МОРСЬКОГО УНІВЕРСИТЕТУ

№ 2 (65), 2021
HERALD

OF THE ODESSA NATIONAL

MARITIME UNIVERSITY № 2 (65), 2021

9. «Yangtze» website. [Electronic source] - Retrieved from: https:// www. yangtze.com/cruise-ships/president-cruises/ (access date 20.01.2021).

10. «Victoria Cruises» website. [Electronic source] - Retrieved from: https://www.victoriacruiselines.com/ (access date 20.01.2021).

11. «Yangtze Gold Cruises» website. [Electronic source] - Retrieved from: http://yangtzegoldcruises.com/aspx/en/index.aspx (access date 20.01.2021).

12. «Sanctuary Retreats» website. [Electronic source] - Retrieved from: https://www.sanctuaryretreats.com/china-cruises-yangziexplorer (access date 20.01.2021).

13. «Maritime Executive» website. [Electronic source] - Retrieved from: https://maritime-executive.com/corporate/schottel-propulsion-for-next-generation-yangtze-cruise-vessel (access date 20.01.2021).

14. "World Tourism Cities Federation Cruise Brach» website. [Electronic source] - Retrieved from: http://www.cciwtcf.org/ work/ showproduct.php? lang=cn\&id=258 (access date 20.01.2021).

15. "China Highlights» website. [Electronic source] - Retrieved from: https://www.chinahighlights.com/yangtzecruise/yangzi-explorer/ (access date 20.01.2021).

16. «Borders of Adventure» website. [Electronic source] - Retrieved from: https://www.bordersofadventure.com/ yangtze_river_cruise_ local_not_luxury_travel/ (access date 20.01.2021).

17. "Asocial No Mad̄» website. [Electronic source] - Retrieved from: https://asocialnomad.com/china/yangtze-river-cruise-chinese-boat/ (access date 20.01.2021).

Стаття надійшла до редакиії 15.04.2021

Посилання на статтю: Єгоров О.Г. Аналіз флоту річкових круїзних пасажирських суден Китаю // Вісник Одеського національного морського університету: Зб. наук. праць, 2021. № 2(65). C. 47-83. DOI 10.47049/ 2226-18932021-2-47-83.

Article received 15.04.2021

Reference a JournalArtic: Egorov A. Analysis of Chinese river cruise passenger ships // Herald of the Odessa national maritime university. 2021. 2(65). 47-83. DOI 10.47049/ 2226-1893-2021-2-47-83. 